\title{
Abstracts voorjaarsvergadering NVU, 25 mei 2018, Nijmegen
}

\section{Prospectieve validatie van een diagnostische urinetest voor blaaskanker: de HEMAturie-studie}

\author{
J.J. de Jong, K.E.M. van Kessel, A.C.J. Ziel-van der Made, \\ H. Roshani, S.M. Haensel, J.H. van Montfrans-Wolterbeek, \\ E.R. Boevé, E.H.G.M. Oomens, N.J. van Casteren, J.L. \\ Boormans, W. van Criekinge en E.C. Zwarthoff \\ Erasmus MC Kanker Instituut, Rotterdam
}

\section{Introductie}

Bij 2-5\% van de microscopische hematurie- en $10-28 \%$ van de macroscopische hematuriepatiënten blijkt een blaastumor de oorzaak van de hematurie te zijn. Eerder hebben wij een urinetest op basis van mutatie- en methylatiemarkers ontwikkeld om blaaskanker te detecteren ( $97 \%$ sensitiviteit en $83 \%$ specificiteit). De nauwkeurigheid van deze test is reeds gevalideerd in een onafhankelijk retrospectief internationaal cohort en bleek robuust (93\% sensitiviteit en $86 \%$ specificiteit). Hier presenteren wij de eerste resultaten van de validatie van deze urinetest in een groot prospectief verzameld cohort van hematuriepatiënten.

\section{Materiaal en methoden}

Prospectief zijn 1.003 patiënten die naar de uroloog werden verwezen voor macroscopische of microscopische hematurie, geïncludeerd uit zes ziekenhuizen in Nederland. Van patiënten werd voorafgaand aan de diagnostische cystoscopie een urinemonster afgenomen. Patiënten jonger dan 18 jaar en/of met blaaskanker in de voorgeschiedenis werden geexcludeerd. DNA werd geïsoleerd en geanalyseerd op mutaties in de FGFR3-, TERT- en HRAS-genen middels enkele-nucleotide extensiereactie (Snapshot). Methylering van de OTX1-, ONECUT2- en TWIST1-genen werd bepaald via methylatiespecifieke polymerase kettingreactie.

\footnotetext{
$\bar{\triangle}$ dr. Henk G. van der Poel

h.vd.poel@nki.nl
}

Tijdschrift voor Urologie,

Bohn Stafleu van Loghum, Houten, Nederland

\section{Resultaten}

Van alle patiënten was $60,6 \%$ man en $39,4 \%$ vrouw. $45,7 \%$ presenteerde zich met microscopische hematurie en 54,3\% met macroscopische hematurie. In het totaal werden er 119 patiënten gediagnosticeerd met blaaskanker. De urinetest resulteerde in $88 \%$ sensitiviteit, $89 \%$ specificiteit, een negatief-voorspellende waarde van $99 \%$ en een predictieve capaciteit van 0,94 .

\section{Conclusie}

Volgens de huidige richtlijnen ondergaan bijna alle hematuriepatiënten een cystoscopie, maar slechts $3-28 \%$ zal worden gediagnosticeerd met blaaskanker. Er is een duidelijke klinische behoefte aan een test die in staat is hematuriepatiënten te selecteren, waarbij een diagnostische scopie nodig is. Onze urinetest bleek robuust in dit prospectief verzamelde cohort en is gereed voor klinische implementatie.

\section{Invloed van een LUTS/BPH-keuzehulp op de behandelkeuze: resultaten van een prospectieve studie vergeleken met een historische controle- groep}

P.J.M. Kil, F.C. van der Wijden, I.B. de Angst, M. Cuypers, M. de Vries, R.E.D. Lamers, H.H.E. van Melick, J.S. de Beij, D.J.A.J. Oerlemans en C. Van de Beek Elisabeth-TweeSteden Ziekenhuis, Tilburg

\section{Introductie}

Volgens richtlijnen dient bij medische besluitvorming rekening te worden gehouden met de voorkeuren van de individuele patiënt met LUTS/BPH. Om deze persoonlijke voorkeuren te achterhalen is, in opdracht van de NVU, een keuzehulp ontwikkeld. Dit onderzoek beschrijft de invloed van de keuzehulp op het verbeteren van de behandelkeuze bij LUTS/BPH, waarbij gekeken is naar het effect van de keuzehulp op de overeenkomst tussen hun beter geïnformeerde voorkeuren en uiteindelijke behandelkeuze. 


\section{Methode}

In vijf ziekenhuizen werd tussen juli 2016 en januari 2017 aan nieuwe patiënten met LUTS/BPH de keuzehulp uitgereikt. Tegelijkertijd werden zij uitgenodigd om deel te nemen aan een vragenlijstonderzoek. De resultaten werden vergeleken met een historische controlegroep van LUTS/ BPH-patiënten die tussen december 2015 en februari 2016 de uroloog hadden bezocht. Voor het evalueren van de primaire uitkomst werd een kennisvragenlijst gebruikt en werd gekeken naar de relatie tussen antwoorden op preferentiegevoelige stellingen en uiteindelijke behandelkeuze. Overige uitkomsten waren: decisional conflict, mate van betrokkenheid, spijt en invloed op behandelkeuze.

\section{Resultaten}

109 keuzehulpgebruikers en 108 controlepatiënten werden geïncludeerd. Keuzehulpgebruikers waren jonger dan controlepatiënten $(68,4 v s .71,5$ jaar; $p=0,003)$ en waren hoger opgeleid $(p=0,047)$. Keuzehulpgebruikers maakten vaker dan controlepatiënten een beter geïnformeerde keuze die overeenkwam met de voorkeuren van de patiënt $(43 \%$ vs. $21 \% ; p=0,026)$. Decisional conflict was lager in de keuzehulpgroep $(33,2$ vs. 46.6; $p=0,005)$. Verder kozen keuzehulpgebruikers, zonder medicatie in de voorgeschiedenis, vaker leefstijladviezen dan controlepatiënten $(p=0,009)$. Overige uitkomsten toonden geen verschil.

\section{Conclusie}

De LUTS/BPH-keuzehulp ondersteunt de besluitvorming en verbetert het keuzeproces doordat patiënten een beter ge- informeerde keuze maken, die meer overeenkomt met hun persoonlijke voorkeuren. Daarnaast leidt het gebruik van de keuzehulp tot meer conservatieve behandelkeuzes bij patiënten die nog geen medicatie hebben gebruikt.

\section{3a. De FUTURE trial: een RCT naar MRI-geleide prostaatbiopten. Vergelijking van drie technieken van targetbiopten}

O. Wegelin, L. Exterkate, D.M. Somford, J.O. Barentsz, M. van der Leest, J.A. Kummer, W. Vreuls, P.C. de Bruin, R. Laduc, T.F. de Vocht, J.L.H.R. Bosch en H.H.E. van Melick St. Antonius Ziekenhuis, Nieuwegein/Utrecht

\section{Introductie}

De richtlijn adviseert een multiparametrische MRI (mpMRI) te verrichten bij patiënten na eerdere negatieve systematische prostaatbiopten en een blijvende verdenking op prostaatkanker (pCa). Indien er een verdachte afwijking op de mpMRI wordt gezien, dient deze gevolgd te worden door target prostaatbiopten (TB). Er zijn drie technieken voor TB en er is geen consensus over welke techniek de voorkeur verdient. In deze analyse vergelijken we de uitkomsten van drie technieken van TB.

\section{Materiaal en methoden}

Tussen 2014 en 2017 werd bij 665 mannen na eerdere negatieve biopten en een blijvende verdenking op $\mathrm{PCa}(\mathrm{pSA} \geq 4$ en/of een afwijkend rectaal toucher) een mpMRI verricht.

Tabel 3a-1 Resultaten

\begin{tabular}{|c|c|c|c|c|}
\hline & $\begin{array}{l}\text { MRI-TRUS-fusie } \\
(n=79)\end{array}$ & $\begin{array}{l}\text { in-bore MRGB } \\
(n=77)\end{array}$ & $\begin{array}{l}\text { cognitieve TRUS } \\
(n=78)\end{array}$ & $p$ \\
\hline leeftijd (gem.) & 64,6 & 66,0 & 66,5 & 0,17 \\
\hline PSA (gem.) & 11,6 & 11,0 & 11,0 & 0,90 \\
\hline volume op TRUS (gem.) & 45,4 & 48,3 & 48,5 & 0,49 \\
\hline klinisch stadium (RT) & & & & 0,36 \\
\hline cT0 & $74,7 \%(59)$ & $83,1 \%(64)$ & $84,6 \%(66)$ & \\
\hline $\mathrm{cT} 2 \mathrm{a} / \mathrm{b}$ & $20,3 \%(16)$ & $13,0 \%(10)$ & $14,1 \%(11)$ & \\
\hline $\mathrm{cT} 2 \mathrm{c}$ & $3,8 \%(3)$ & $1,3 \%(1)$ & $0,0 \%(0)$ & \\
\hline $\mathrm{cT} 3 \mathrm{a}$ & $1,3 \%(1)$ & $2,6 \%(2)$ & $1,3 \%(1)$ & \\
\hline aantal eerdere negatieve biopten (gem.) & 1,4 & 1,5 & 1,4 & 0,71 \\
\hline MRI-uitkomst & & & & 0,75 \\
\hline PIRADS 3 & $29,1 \%(23)$ & $26,0 \%(20)$ & $26,9 \%(21)$ & \\
\hline PIRADS 4 & $43,0 \%(34)$ & $45,5 \%(35)$ & $41,0 \%(32)$ & \\
\hline PIRADS 5 & $27,8 \%(22)$ & $28,6 \%(22)$ & $32,1 \%(25)$ & \\
\hline aantal laesies op MRI (gem.) & 1,1 & 1,1 & 1,1 & 0,88 \\
\hline laesiegrootte in mm (gem.) & 13,9 & 13,6 & 12,9 & 0,63 \\
\hline aantal biopten (gem.) & 4,5 & 2,6 & 3,5 & $<0,05$ \\
\hline detectie overall $\mathrm{PCa}$ & $49,4 \%$ & $54,5 \%$ & $43,6 \%$ & 0,39 \\
\hline detectie significant $\mathrm{PCa}($ Gleason $\geq 7$ ) & $34,2 \%$ & $32,5 \%$ & $33,3 \%$ & 0,98 \\
\hline
\end{tabular}


De beelden werden centraal geëvalueerd door een expert radioloog volgens PIRADS v2. Wanneer mpMRI een PIRADS $\geq 3$-laesie toonde, werden patiënten 1:1:1 gerandomiseerd voor een van de drie technieken van TB (transperineale MR-TRUS-fusie, in-bore MRGB, cognitieve TRUS). De detectiepercentages van $\mathrm{PCa}$ en significant $\mathrm{PCa}(\mathrm{sPCa}=$ Gleason $\geq 7$ ) werden vergeleken met behulp van de chikwadraattoets.

\section{Resultaten}

Bij 234 (35,2\%) geïncludeerde patiënten toonde de mpMRI een PIRADS $\geq 3$. Deze patiënten werden gerandomiseerd en ondergingen TB. Er waren geen verschillen in baselinekarakteristieken of PIRADS-score $(p=0,75)$ binnen de drie groepen (zie tabel 3a-1). Met behulp van TB werd in 49,1\% $\mathrm{PCa}$ vastgesteld en in 33,3\% sPCa. De detectiepercentages van $\mathrm{PCa}(p=0,39)$ en $\mathrm{SPCa}(p=0,98)$ waren niet significant verschillend tussen de drie groepen (zie tabel 3a-1). Er werd enkel een significant verschil gezien in het aantal afgenomen biopten $(p<0,05)$.

\section{Conclusie}

Bij het merendeel van de patiënten $(64,8 \%)$ laat een mpMRI na negatieve prostaatbiopten PIRADS $\leq 2$ zien. Er is geen significant voordeel voor één specifieke techniek voor MRI-geleide targetbiopten bij de detectie van (significant) PCa bij patiënten met een PIRADS $\geq 3$ op mpMRI na negatieve systematische biopten. Deze resultaten komen overeen met eerder gepubliceerde data.

\section{3b. De FUTURE trial: een RCT naar MRI-geleide prostaatbiopten. Vergelijking van target- en systematische biopten}

L. Exterkate, O. Wegelin, H.H.E. van Melick, J.O. Barentsz, M. van der Leest, J.A. Kummer, W. Vreuls, P. de Bruin, J.L.H.R. Bosch, R. Laduc, T.F. de Vocht en D.M. Somford Canisius-Wilhelmina Ziekenhuis, Nijmegen

\section{Introductie}

Richtlijnen adviseren een multiparametrische MRI (mpMRI) te verrichten bij patiënten na eerdere negatieve systema- tische prostaatbiopten (SB) en een persisterende verdenking op prostaatkanker (PCa), met als doel targetbiopten (TB) te verrichten wanneer sprake blijkt van een voor PCa verdachte afwijking. In deze analyse van de FUTURE-trial wordt de prostaatkankerdetectie van deze TB vergeleken met die van SB.

\section{Materiaal en methoden}

Tussen 2014 en 2017 werd bij 665 mannen na eerdere negatieve $\mathrm{SB}$ en een persisterende verdenking op $\mathrm{PCa}(\mathrm{pSA} \geq 4$ en/of een afwijkend rectaal toucher) een mpMRI verricht. De beelden werden centraal geëvalueerd door een expert radioloog volgens PIRADS v2. Wanneer de mpMRI een PIRADS $\geq 3$-laesie toonde, werden patiënten 1:1:1 gerandomiseerd voor TB (cognitieve TRUS, MR-TRUS fusie, in-bore MRI). In de cognitieve fusie- en MR-TRUS-fusiegroep werden TB verricht, gevolgd door SB volgens een gestandaardiseerde template, onafhankelijk van de locatie van de laesies op de mpMRI. De detectiepercentages van $\mathrm{TB}$ en $\mathrm{SB}$ voor PCa en significant PCa (sPCa) (Gleason $\geq 7$ ) werden vergeleken middels de McNemar-test.

\section{Resultaten}

Bij 234 patiënten $(35,2 \%)$ werd een PIRADS $\geq 3$-laesie op mpMRI gevonden en werden TB verricht. 152 patiënten ondergingen zowel TB als SB. Middels SB werd bij 46,7\% $(n=71)$ PCa gevonden en bij 33,6\% $(n=51)$ sPCa (zie tabel 3b-1). TB detecteerden zowel significant meer PCa $(p=$ $0,002)$ als sPCa $(p=0,000)$ dan SB. Bij patiënten bij wie SB geen PCa detecteerden, werd middels TB alsnog bij 21,0\% $(n=32)$ PCa en bij 13,8\% $(n=21)$ sPCa gevonden. Bij patiënten bij wie TB geen PCa toonden, werd met SB in $6,6 \%$ $(n=10)$ van de gevallen PCa en in $1,3 \%(n=2)$ van de gevallen sPCa gedetecteerd. SB detecteerden insignificant $\mathrm{PCa}$ bij 5,3\% $(n=8)$ van de patiënten bij wie TB geen PCa vond.

\section{Conclusie}

Gerichte biopten laten een sterke stijging zien in de detectie van (significant) PCa ten opzichte van systematische biopten bij patiënten met eerdere negatieve prostaatbiopten. Indien alleen gerichte biopten afgenomen zouden worden, zou er nauwelijks significant PCa worden gemist en zou er minder insignificant PCa worden gevonden.

Tabel 3b-1. Biopsie-uitkomsten

\begin{tabular}{|c|c|c|c|c|c|}
\hline & & \multicolumn{3}{|c|}{ systematische biopten } & \multirow[t]{2}{*}{ totaal } \\
\hline & & geen $\mathrm{PCa}$ & Gleason $=6$ & Gleason $\geq 7$ & \\
\hline \multirow{3}{*}{ targetbiopten } & geen $\mathrm{PCa}$ & $71(46,7 \%)$ & $8(5,3 \%)$ & $2(1,3 \%)$ & 81 \\
\hline & Gleason $=6$ & $11(7,2 \%)$ & $9(5,9 \%)$ & $0(0,0 \%)$ & 20 \\
\hline & Gleason $\geq 7$ & $21(13,8 \%)$ & $8(5,3 \%)$ & $22(14,5 \%)$ & 51 \\
\hline totaal & & 103 & 25 & 24 & $n=152$ \\
\hline
\end{tabular}




\section{Testicular Sperm Value (TSV) als predictor van zwangerschapskans en laboratoriummanagement- instrument bij intracytoplasmatische sperma- injectie met testiculaire zaadcellen (TESE-ICSI)}

W.P.A. Boellaard, J. Speksnijder, J. Laven, M. Dinkelman-Smit, G.R. Dohle en G.W. van der Heijden

Erasmus MC, Rotterdam

\section{Introductie}

Omdat er geen universele manier bestaat om de kwaliteit van testiculaire spermaextractie (TESE) te classificeren, hebben wij een methode ontwikkeld van gestandaardiseerde kwantificatie van zaadcellen vooraf aan cryopreservatie van het TESE-biopt, met als doel dit te gebruiken als kwaliteitsindicator voor de uitkomst van TESE-ICSI.

\section{Materiaal en methoden}

In de periode 2014-2017 werden 223 TESE-ICSI-procedures verricht met zaadcellen van 163 mannen met een azoöspermie. Het testiculaire biopsiemateriaal werd in medium met een microscoopglaasje vermalen tot een celsuspensie. Hiervan werd $10 \mu \mathrm{l}$ onder de microscoop beoordeeld. Het percentage gezichtsvelden (GV) met een zaadcel (ZC) werd genoteerd. Bij lage aantallen zaadcellen werd het gehele glaasje bekeken $(250 \mathrm{GV})$. Bij het zien van ten minste één zaadcel per $250 \mathrm{GV}$ werd het materiaal ingevroren. De testicular sperm value (TSV) werd berekend als ZC/GV*100. Op de dag van ICSI werd TESE-materiaal ontdooid en gezocht naar vitale zaadcellen voor oöcytinjectie. De duur van de TESE-ICSI-procedure werd genoteerd.

\section{Resultaten}

Uit de 223 TESE-ICSI bij 163 paren kwamen 87 zwangerschappen voort. Bij mannen met TSV $\leq 0,8(n=15)$ was de cumulatieve kans op zwangerschap lager dan bij mannen met TSV 1-40 ( $n=56)(13 \%$ vs. 57\%). De cumulatieve kans op zwangerschap bij mannen met TSV $>40$ was $61 \%$. Bij TSV $>25$ duurde de procedure gemiddeld 2 uur, bij TSV $8-25$ was dit 4 uur en bij TSV $<86,5$ uur.

\section{Conclusie}

Gestandaardiseerde kwantificatie van zaadcellen in TESEbiopten door middel van de TSV is een goede kwaliteitsindicator voor de cumulatieve kans op zwangerschap na TESE-ICSI. Patiënten met een TSV $<1$ kunnen gecounseld worden op lagere cumulatieve kans op zwangerschap (13\%), terwijl deze goed is bij TSV $>1$ (57-61\%). Deze studie toont aan dat TSV negatief correleert met de duur van de TESE-ICSI-procedure. TSV kan als kwaliteitsindicator gebruikt worden om de planning en bedrijfsvoering op IVF-laboratoria te optimaliseren.

\section{Het effect op de overleving van androgeen- deprivatietherapie vergeleken met androgeen- deprivatietherapie in combinatie met externe radiotherapie op de prostaat alleen bij patiënten met een primair ossaal gemetastaseerd prostaat- carcinoom in een prospectieve gerandomiseerde studie: resultaten van de HORRAD-studie}

L.M.S. Boevé, M.C.C.M. Hulshof, A.N. Vis, A.H. Zwinderman, J.W.R. Twisk, W.P.J. Witjes, K.P.J. Delaere, R.J.A. van

Moorselaar, P.C.M.S. Verhagen en G. van Andel

OLVG, Amsterdam

\section{Introductie}

Androgeendeprivatietherapie (ADT) is de hoeksteen van de behandeling voor patiënten met een primair ossaal gemetastaseerd prostaatcarcinoom ( $\mathrm{mPCa}$ ). Uit de literatuur is bekend dat lokale behandeling van de primaire tumor bij andere vormen van gemetastaseerde ziekte leidt tot overlevingswinst. Het doel van deze studie is om te bepalen of lokale behandeling van de primaire tumor van de prostaat met externe radiotherapie bij patiënten met $\mathrm{mPCa}$ ook leidt tot verlenging van de overlevingsduur.

\section{Materiaal en methoden}

In deze prospectieve, gerandomiseerde, multicenterstudie werden tussen 2004 en 2014432 patiënten met een primair ossaal gemetastaseerd prostaatcarcinoom geïncludeerd. Deze patiënten werden gerandomiseerd tussen ADT in combinatie met externe radiotherapie op de prostaat (radiotherapiegroep) en ADT alleen (controlegroep). Het primaire eindpunt is het effect op de overlevingsduur, welke werd geanalyseerd met de Kaplan-Meiermethode en Cox-regressie.

\section{Resultaten}

De mediane overleving was 45 maanden $(95 \%$-BI $=40,4$ $49,6)$ in de radiotherapiegroep en 43 maanden $(32,6-53,4)$ in de controlegroep. In figuur 5.1 wordt de Kaplan-Meiercurve van de overleving weergegeven ( $p=0,356)$. Cox-regressieanalyses lieten geen significant verschil zien in de overlevingsduur tussen beide groepen, noch bij de univariate (hazard ratio $(\mathrm{HR}) 0,90 ; 95 \%-\mathrm{BI}=0,70-1,14 ; p=0,35$ ) noch bij multivariate analyse (HR 1,11; 95\%-BI $=0,87$ $1,43 ; p=0,41)$. Een multivariate subgroepanalyse liet bij patiënten met een PSA kleiner dan de mediaan $(145 \mathrm{ng} / \mathrm{ml})$, $<5$ ossale metastasen en een Gleason-score $\leq 8$, een HR van 0,43 zien, hoewel dit niet statistisch significant was $(95 \%$ $\mathrm{BI}=0,17-1,05 ; p=0,063)$.

\section{Conclusie}

In deze gerandomiseerde studie wordt geen significant verschil in overlevingsduur gezien bij patiënten met een primair ossaal gemetastaseerd prostaatcarcinoom die behan- 


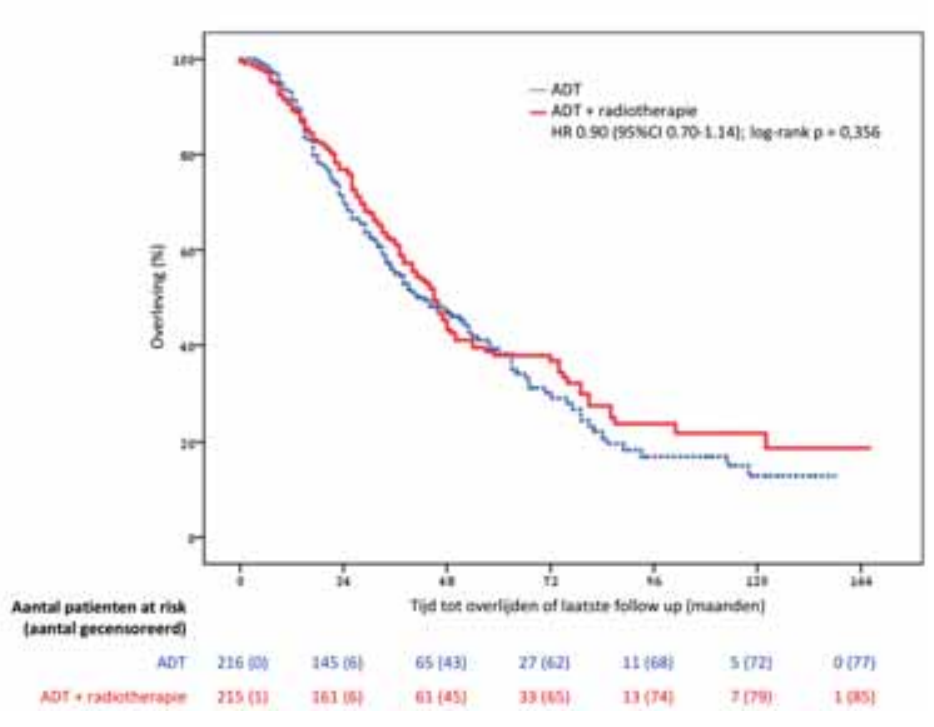

Figuur 5.1 Kaplan-Meier-curve van de overleving

deld worden met externe radiotherapie op de prostaat in combinatie met ADT, in vergelijking met ADT alleen. Mogelijk is er een voordeel van lokale behandeling bij patiënten met oligometastasen, maar dit verschil is niet statistisch significant.

\section{Leukaferese is een veilige en efficiënte methode voor de verrijking van circulerende tumorcellen van gemetastaseerd prostaatcarcinoom}

L.F. van Dessel, L. Mout, J. Kraan, S. Erkens-Schulze,

P. Hamberg, P.A.W. te Boekhorst, R. de Wit, J.W.M. Martens,

W.M. van Weerden en M.P. Lolkema

Erasmus MC, Rotterdam

\section{Introductie}

Bij patiënten met gemetastaseerd prostaatcarcinoom (mPCa) zijn vaak circulerende tumorcellen (CTC's) aanwezig in het bloed. Deze zijn afkomstig van de primaire tumor en metastasen, en representeren hierdoor de heterogeniteit van de ziekte. CTC's zijn dus een interessante bron voor analyses van verscheidene tumorkarakteristieken. Echter, hiervoor zijn grote aantallen CTC's nodig, waarvoor een bloedafname vaak onvoldoende is. Leukaferese (LA) is een gevalideerde techniek voor het verkrijgen van grote aantallen mononucleaire bloedcellen. Het doel van deze studie was om een LA-procedure te ontwikkelen voor het efficiënt isoleren van CTC's uit bloed, om deze vervolgens te kweken ten behoeve van karakterisering en therapiescreening.

\section{Materiaal en methoden}

24 mPCa-patiënten werden gescreend op het aantal CTC's in bloed. Alleen bij patiënten met $\geq 5$ CTC's per 7,5 ml bloed werd LA toegepast. Maximaal 10 L bloed werd gebruikt voor LA. Uit het verkregen LA-product werden CTC's verrijkt door middel van depletie van leukocyten, al dan niet gevolgd door een selectie voor CTC's. Uitkomstmaten van de studie waren: (1) het aantal (serious) adverse events ((S) AEs) > 48 uur na LA, (2) CTC-opbrengst (\% van verwachte totaal), (3) verrijking van CTC's uit LA-product, en (4) succesvol kweken van CTC's.

\section{Resultaten}

$13 / 24$ patiënten hadden bij screening $\geq 5$ CTC's per 7,5 ml bloed, met een mediaan aantal van 13 (spreiding: 5-199). Tot dusver hebben 10 patiënten LA ondergaan, waarvan geen enkele patiënt $>48$ uur na LA een (S)AE rapporteerde. De mediane CTC-opbrengst in het LA-product was $43 \%$ (range: 33-95\%) met een mediaan aantal van 15.339 (spreiding: 4.692-30,470). Verrijking van CTC's uit het LA-product door depletie van leukocyten leverde een mediane opbrengst van $65 \%$ op. Indien aansluitend een CTC-selectie werd uitgevoerd, was de mediane opbrengst 29\%. Momenteel hebben we 1/10 gekweekte CTC's kunnen karakteriseren.

\section{Conclusie}

LA is een veilige en efficiënte methode voor het verkrijgen van grote aantallen CTC's van mPCa-patiënten. Echter, het verrijken van CTC's uit LA-product en het succesvol kweken van deze CTC's is uitdagend en vergt verdere optimalisatie.

\section{MRI voor het beoordelen van snijranden en pseudokapseleigenschappen na partiële nefrectomie}

T.J. van Oostenbrugge, W. Runneboom, E. Bekers, J. Heidkamp, J.F. Langenhuijsen, A. Veltien, A. Maat, J.J. Fütterer,

C.A. Hulsbergen-van de Kaa, P.F.A. Mulders

Radboudumc, Nijmegen

\section{Introductie}

Het streven bij een partiële nefrectomie (PN) is om oncologisch radicaal te zijn en daarnaast zo veel mogelijk gezond nierparenchym te behouden. Ex-vivobeeldvorming van preparaten na PN zou de uroloog hierbij kunnen faciliteren. Doel van deze studie was om de haalbaarheid te evalueren van ex-vivo-MRI om snijranden en pseudokapseleigenschappen van het preparaat te beoordelen na PN.

\section{Materiaal en methoden}

In deze prospectieve studie zijn zeven patiënten die een PN ondergingen voor negen tumoren tussen november 2014 en juli 2015 geïncludeerd voor analyse na het verkrijgen van informed consent. MRI van het preparaat werd gedaan met 

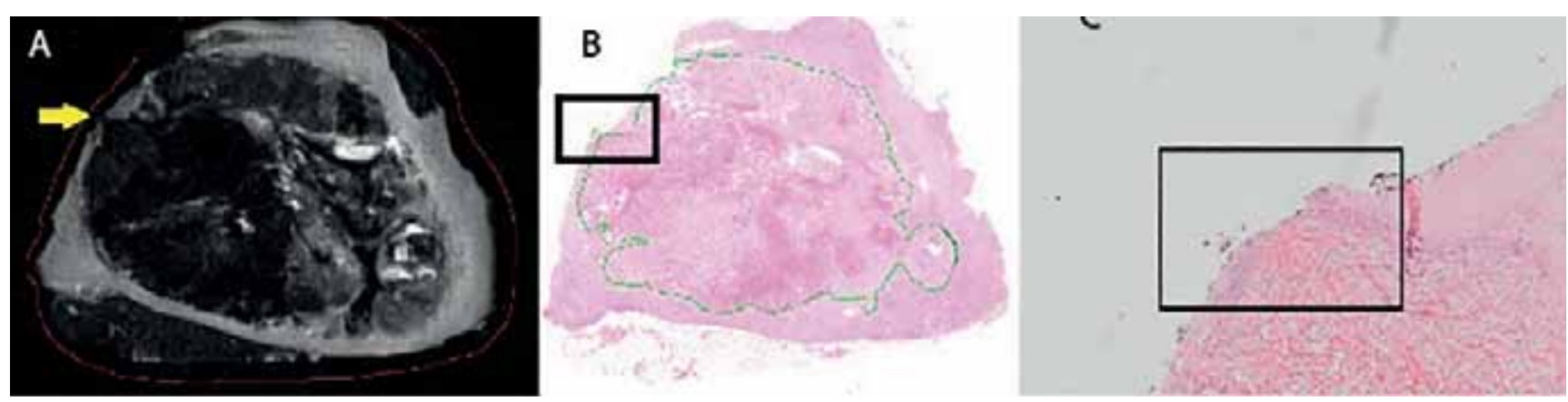

Figuur 7.1 De T2-gewogen scan van een preparaat (endofytisch groeiende tumor) na resectie laat verdenking op een positieve (gele pijl) snijrand (rode lijn) zien (A). Bijbehorende H\&E-coupe welke gescand en geannoteerd is, bevestigt de positieve snijrand in de zwarte rechthoek (B). In detail blijkt de snijrand in de zwarte rechthoek positief over 1,4 $\mathrm{mm}(\mathrm{C})$.

een 7T-small bore MR-scanner. Het scanprotocol bestond uit anatomische T1-, T2- en diffusiegewogen opnames. Na de scan werden de preparaten in formaline gefixeerd en voor pathologische work-up gesneden in dezelfde richting als de verkregen MRI-afbeeldingen. Het volledige preparaat werd verwerkt in H\&E coupes welke digitaal werden gescand en geannoteerd. MRI-bevindingen voor negatieve snijranden, aanwezigheid van een pseudokapsel, pseudokapselcontinuïteit en -doorgroei werden gecorreleerd met histopathologie. De sensitiviteit en specificiteit van MRI voor het beoordelen van deze eindpunten werden berekend.

\section{Resultaten}

De sensitiviteit en specificiteit voor de beoordeling van de snijranden waren $100 \%$ (9/9) en 75\% (6/8). Twee fout-positieve uitkomsten werden gevonden. Beide hadden pseudokapseldoorgroei en een krapste-resectiemarge (nierparenchym-randtumor) van $\leq 0,5 \mathrm{~mm}$. Sensitiviteit en specificiteit voor de aanwezigheid van een pseudokapsel waren $100 \%$ $(6 / 6)$ en $33 \%(1 / 3)$. Twee fout-positieve scans met anatomische structuren die werden aangezien voor pseudokapsel werden gerapporteerd. Wanneer een pseudokapsel aanwezig was, konden de pseudokapselcontinuïteit en -doorgroei worden bepaald met een sensitiviteit en specificiteit van $75 \%(3 / 4)$ en $100 \%(2 / 2)$ en $67 \%(2 / 3)$ en $100 \%(3 / 3)$.

\section{Conclusie}

Beoordeling van snijranden en, indien aanwezig, eigenschappen van het pseudokapsel na PN is mogelijk met exvivo-MRI. Dit kan het maximaal sparen van nierparenchym faciliteren zonder de oncologische uitkomsten te compromitteren.

\section{De invloed van het antibioticabeleid na Green Light Lasertherapie op het aantal urineweg- infecties}

M.H.W. Mosch, J.F. Langenhuijsen, J.C.M. Kusters, E. Kolwijck en F.C.H. d'Ancona

Radboudumc, Nijmegen

\section{Introductie}

Green Light Laser (GLL) operatie van de prostaat is een effectieve en geaccepteerde behandeling voor symptomatische benigne prostaathyperplasie (BPH). Een complicatie na een GLL-operatie die regelmatig optreedt, is een urineweginfectie (UWI). Om dit te voorkomen, wordt profylactisch antibiotica gegeven. Desondanks zijn er nog steeds veel UWI's. In dit retrospectieve onderzoek is gekeken naar de risicofactoren voor het krijgen van een postoperatieve UWI en de invloed van een extra postoperatieve antibioticumkuur na de GLL-operatie naast de gebruikelijke antibioticaprofylaxe.

\section{Materiaal en methoden}

Het betreft een retrospectieve analyse van 439 patiënten die in de periode december 2012 tot en met december 2016 een GLL-operatie ondergingen voor symptomatische BPH. In de eerste periode $(n=99)$ werd er postoperatief geen antibioticum gegeven (groep A). Bij de laatste 340 patiënten (groep B) werd er op basis van risicofactoren een indicatie voor wel/niet antibioticum postoperatief bepaald. Risicofactoren: preoperatieve retentie en/of een prostaatgrootte $>80 \mathrm{cc}$. Gekeken is naar de invloed van deze risicofactoren op het krijgen van de UWI.

\section{Resultaten}

In groep B was het percentage UWI's 19,4\%. In groep A $27,3 \%$. Binnen groep B heeft niet iedereen daadwerkelijk postoperatief een antibioticum gekregen op indicatie, omdat een duidelijke richtlijn ontbrak. De groep met indicatie en 
behandeling $(n=98)$ had in $15,25 \%$ een UWI terwijl de groep met indicatie zonder behandeling $(n=99)$ in $26,3 \%$ van de gevallen een UWI kreeg. Het hebben van urineretentie preoperatief gaf in groep A ruim vijf keer zo grote kans op het krijgen van een UWI in vergelijking met geen urineretentie. In de groep B was deze kans nog twee keer zo groot. Er was geen onderscheid aantoonbaar in postoperatieve UWI's tussen groepen met prostaten $>$ of $<$ dan $80 \mathrm{cc}$.

\section{Conclusie}

Er is een duidelijke daling van het UWI-percentage in deze patiëntengroep opgetreden sinds het gebruik van een extra postoperatief antibioticum op indicatie. Er is een hogere incidentie van UWI's in vergelijking met de literatuur. Een nieuwe richtlijn voor postoperatieve profylaxe lijkt noodzakelijk.

\section{Refertilisatie na vasectomie: (Hoe) doet u het?}

M. Dinkelman-Smit, J.H. van Roijen, K. Fleischer, J. Knijnenburg, K.W.M. D’Hauwers, A. Meißner, G.W. van der Heijden en I. Mostovaya

Erasmus MC, Rotterdam

\section{Introductie}

Ter voorbereiding op de ontwikkeling van de richtlijn obstructieve azoöspermie werd een enquête uitgezet onder NVU-leden. Ervaring met vasovasostomie (VVS) en vasoepididymostomie (VES), indicatiestelling, patiëntvoorlichting en operatietechniek werden geïnventariseerd. Knelpunten in het huidige beleid werden voorgelegd.

\section{Materiaal en methoden}

De enquête werd opgesteld door werkgroepleden die de urologie, gynaecologie, embryologie, patiëntenvereniging en het kennisinstituut vertegenwoordigen. Tussen 2 en 13 oktober 2017 reageerden 50 urologen/aios.

\section{Resultaten}

VVS of VES werd zelfstandig uitgevoerd door 23 respondenten, met mediaan 15 jaar ervaring (spreiding 1-29). Vijf urologen hadden $\leq 2$ jaar ervaring, 13 urologen hadden $>14$ jaar ervaring. Refertilisaties werden maximaal vijf keer per jaar verricht door 13 van de 23 respondenten. Vijf urologen rapporteerden een volume van tien keer per jaar, nog eens vijf meldden $15-50$ keer per jaar. 54\% van de urologen hanteert geen grens van het obstructie-interval waarboven refertilisatie niet meer wordt aangeboden. Partnerleeftijd $>38$ jaar is voor $38 \%$ van de urologen geen reden om geen refertilisatie meer aan te bieden. $30 \%$ vermeldt te counselen op slechte zwangerschapskans bij verminderde ovariële reserve op hogere leeftijd. De refertilisatie wordt uitgevoerd met het blote oog, loepbril of operatiemicroscoop door resp. drie, tien en tien urologen. De respondenten prioriteerden de volgende top drie van knelpunten voor de richtlijn: (1) wat is het belang van het obstructie-interval voor de beslissing refertilisatie versus ICSI met chirurgisch verkregen zaadcellen? (2) hoe groot is het risico op restenose na succesvolle refertilisatie? en (3) met welke techniek is de kans op een kind het grootst en het meest kosteneffectief: refertilisatie of ICSI met chirurgisch verkregen zaadcellen?

\section{Conclusie}

Er is praktijkvariatie in ervaring en uitvoering van refertilisaties in Nederland. Bekende prognostische factoren voor zwangerschap, zoals obstructie-interval en leeftijd van de vrouw, worden door ruim een derde van de urologen die hersteloperaties uitvoeren niet gebruikt bij het nemen van een behandelbeslissing.

\section{Wel of geen re-TURT bij het pTaG3 urotheel- celcarcinoom? Een retrospectieve multicenter- analyse}

O.R. Brouwer, K.T. Buddingh, E.J. van Gennep, C.A. Goossens,

N. Verweij, J. Egberts, J. van der Hoeven, G.F. van Ek en

J. Tijsterman

Haga Ziekenhuis, Den Haag.

\section{Introductie}

Adequate stadiëring bij blaascarcinoom is van wezenlijk belang voor het verdere behandelbeleid. De waarde van een re-resectie na initiële TURT is vooral vastgesteld bij hooggradige T1-tumoren, maar in mindere mate bij niet-invasieve hooggradige tumoren (Ta). De meest recente NVU-richtlijn (2016) adviseert nog om een re-TURT te verrichten bij alle T1-tumoren én alle graad-3-tumoren. In de meest recente EAU-richtlijn (2017) is dit aangepast tot alleen de T1-tumoren, zonder dat deze wijziging expliciet wordt geadresseerd. Deze multicenter retrospectieve studie onderzocht de waarde van een re-TURT specifiek bij het pTaG3-urotheelcelcarcinoom (UCC).

\section{Materiaal en methoden}

Er werd een retrospectieve analyse uitgevoerd waarbij in de vijf deelnemende centra de patiënten geanalyseerd werden bij wie in de periode 2015-2016 bij primaire TURT de diagnose pTaG3 UCC werd gesteld.

\section{Resultaten}

In drie van de vijf centra was het verrichten van een reTURT bij pTaG3 UCC gebruikelijk, in twee centra werd niet standaard een re-TURT verricht. In totaal werd in de deelnemende centra bij 96 patiënten tussen 2015 en 2016 de 
diagnose pTaG3 UCC gesteld. Hiervan ondergingen 29 patiënten een re-TURT. In deze groep was er bij acht patiënten $(27 \%)$ sprake van resttumor. Bij twee hiervan was de primaire TUR irradicaal geacht door de operateur. Bij drie patiënten $(10 \%)$ was er upstaging naar T1/CIS, maar bij geen enkele patiënt naar spierinvasief. In de re-TURTgroep ontwikkelde $24 \%$ een recidief, bij $10 \%$ was er sprake van progressie (bij 1 patiënt spierinvasief). In de groep zonder re-TURT ontwikkelde $27 \%$ binnen één jaar een PAbewezen recidief, bij 12\% met progressie (bij 1 patiënt spierinvasief).

\section{Conclusie}

Het verrichten van een re-TURT bij pTaG3 UCC veranderde in deze studie slechts bij 10\% de initiële stadiëring en dit had bij geen van de patiënten consequenties voor het beleid. Er waren geen significante verschillen in de groep met en zonder re-TURT wat betreft het recidiefpercentage en de progressiekans. Deze studie ondersteunt het achterwege laten van de protocollaire re-TURT bij pTaG3 UCC.

\section{Klinische en patiëntgerapporteerde uitkom- sten na een artificiële urinaire sfincterprothese- plaatsing}

\author{
E.J.V. Oostenbrink, E.R.P. Collette, O.S. Klaver, G.L.S. Pigot en \\ E.J.H. Meuleman \\ VU Medisch Centrum, Amsterdam
}

\section{Introductie}

Implantatie van een artificiële urinaire sfincter (AUS) geldt als gouden standaard voor de behandeling van mannen met therapieresistente urinaire stressincontinentie (SUI). Retrospectief onderzochten wij de klinische alsmede de patiëntgerapporteerde uitkomsten bij mannen na een AUS-implantatie ter behandeling van SUI.

\section{Materiaal en methoden}

89 mannen die tussen 1 januari 2010 en 1 januari 2017 een AUS-implantatie ondergingen vanwege SUI na een prostaatinterventie (TURP, prostatectomie, brachy- of radiotherapie) met een minimale follow-upduur van 12 maanden werden geïncludeerd. Patiënten werden in twee centra geopereerd. Middels database- en vragenlijstonderzoek werden klinische alsmede patiëntgerapporteerde uitkomsten verzameld en geanalyseerd.

\section{Resultaten}

Ten tijde van analyse waren 11 patiënten overleden, de resterende 78 werden aangeschreven. 64\% respondeerde (50/78). De gemiddelde leeftijd en follow-upduur bedroegen $68(50-80)$ resp. $3,8(1,1-7,8)$ jaar. $66 \%(33 / 50)$ onderging enkel een implantatie en 34\% (17/50) een of meer revisies. De aan urine-incontinentie gerelateerde kwaliteit van leven verbeterde van gemiddeld naar goed. Het gemiddelde verbandgebruik reduceerde van 2 tot 3 naar 1 verband per dag na de laatste operatie. $12 \%(6 / 50)$ was droog en $62 \%(31 / 50)$ gebruikte tot en met 1 verband per dag. De IPSS-score bedroeg postoperatief gemiddeld 8 . Achteraf is $70 \%(35 / 50)$ (zeer) tevreden over de keuze van de behandeling, geeft $82 \%(41 / 50)$ opnieuw de voorkeur aan dezelfde behandeling en beveelt $88 \%$ (44/50) dezelfde behandeling aan een vriend.

\section{Conclusie}

De meerderheid van de mannen is na een AUS-implantatie ten gevolge van SUI na een prostaatinterventie tevreden tot zeer tevreden en rapporteert een goede kwaliteit van leven. $\mathrm{Er}$ is een relatief hoge kans op heroperatie. Ondanks diens status als gouden standaard moet tegenover de patiënt worden benadrukt dat de AUS de continentie kan verbeteren, niet oplossen.

\section{Metrische substadiëring is een sterke prognostische factor bij T1-Blaaskanker}

\author{
E.E. Fransen van de Putte, W. Otto, A. Hartmann, J. Bründl, \\ Q. Manach, E.M. Compérat, J.L. Boormans, J. Bosschieter, \\ M.A.S. Jewett, G.J.L.H. van Leenders, J.A. Nieuwenhuijzen, \\ K. Hendricksen, M. Rouprêt, M. Burger, T.H. van der Kwast en \\ B.W.G. van Rhijn \\ Antoni van Leeuwenhoek, Amsterdam
}

\section{Introductie}

T1-blaascarcinomen (T1-BC) vormen een therapeutische uitdaging, waarbij gekozen moet worden tussen conservatieve behandeling en cystectomie. In deze multicenter studie onderzochten we de prognostische waarde van twee substadiëringsmethoden voor T1-BC.

\section{Materiaal en methoden}

Geïncludeerd werden 601 patiënten met primair T1-BC die waren behandeld met ten minste één BCG-inductieschema in vier internationale centra tussen 1983 en 2006 . Twee pathologen reviseerden de TUR-coupes en substadieerden T1-BC volgens twee classificaties: metrisch, met T1-micro-invasief (T1m-lamina-propria-invasie $<0,5 \mathrm{~mm}$ ) versus T1-uitgebreid-invasief (T1e-invasie $\geq 0,5 \mathrm{~mm}$ ), en op basis van muscularis-mucosae (MM)-invasie (T1a zonder / T1b met MM-invasie). We onderzochten de prognostische waarde voor progressie ( $\geq$ cT2 en/of N1 en/of M1) en kankerspecifieke overleving (CSS) van beide classificaties met multivariabele Cox-regressie (voorwaardse selectie). Er werd gecorrigeerd voor geslacht, leeftijd, tumorgrootte $(>3 \mathrm{~cm} v s$. 
$\leq 3 \mathrm{~cm}$ ), carcinoma in situ (CIS), en WHO1973- en -2004gradering.

\section{Resultaten}

Mediane leeftijd was 71 (IQR 15) jaar en CIS was aanwezig in $196(33 \%)$ coupes. Bij metrische stadiëring waren 213 (35\%) T1m vs. 388 (65\%) T1e. Op basis van MM-invasie waren $281(47 \%)$ tumoren T1a vs. 320 (53\%) T1b. MM werd in $466(78 \%)$ tumoren geïdentificeerd ter plaatse van de tumorinvasie. Metrische substadiëring was mogelijk in alle tumoren. Bij een mediane follow-up van 5,9 (IQR = 3,3-9,0) jaar hadden 148 (25\%) patiënten progressieve ziekte, $95(16 \%)$ overleden aan $\mathrm{BC}$. Bij Cox-regressie waren T1e-substadiëring ( $\mathrm{HR}=3,8 ; 95 \%-\mathrm{CI}=2,3-6,0)$ en WHO1973-gradering (G3 vs. G2; HR =1,8; 95\%-CI $=1,2$ $2,7)$ voorspellend voor progressie. Prognostisch voor slechtere CSS waren T1e $(\mathrm{HR}=2,7 ; 95 \%$-CI $=1,6-4,8)$, WHO1973-G3 (HR = 2,6; 95\%-CI = 1,4-4,7), leeftijd (HR $=1,03 ; 95 \%-\mathrm{CI}=1,01-1,05)$ en grootte $>3 \mathrm{~cm}(\mathrm{HR}=1,8$; $95 \%-\mathrm{CI}=1,2-2,9)$.

\section{Conclusie}

In deze multicenterstudie bleek metrische $(\mathrm{T} 1 \mathrm{~m} / \mathrm{e})$ substadiëring een sterke prognostische factor voor progressie en CSS. Metrische T1-substadiëring en WHO1973-gradering lijken nuttig bij de keuze tussen conservatieve behandeling en cystectomie.

\section{JJ-katheter verbetert het vroege postoperatie- ve herstel na niertransplantatie}

M.H.D. Bruintjes, M.C. Warlé, J.C.M. Kusters,

J.F. Langenhuijsen, L.B. Hilbrands, F.C.H. d'Ancona

Radboudumc, Nijmegen

\section{Introductie}

Het profylactisch stenten van de ureter bij niertransplantaties vermindert het aantal postoperatieve urologische complicaties. Echter, er is nog geen gouden standaard wat betreft het type te gebruiken stent. Wij hebben vergeleken wat de invloed is van JJ-katheters en splints op het vroege postoperatieve herstel na levende-donorniertransplantatie.

\section{Materiaal en methoden}

In deze prospectieve cohortstudie werden 80 ontvangers van levende-donorniertransplantaties gevolgd in hun vroege postoperatieve herstel. Het eerste cohort van 40 patiënten kreeg een splint, die op dag 5 postoperatief werd verwijderd, gevolgd door de transurethrale katheter op dag 7, volgens het standaardprotocol in ons centrum. Het tweede cohort ontving een JJ-katheter gedurende 2-3 weken, welke werd verwijderd op de polikliniek middels cystoscopie. In

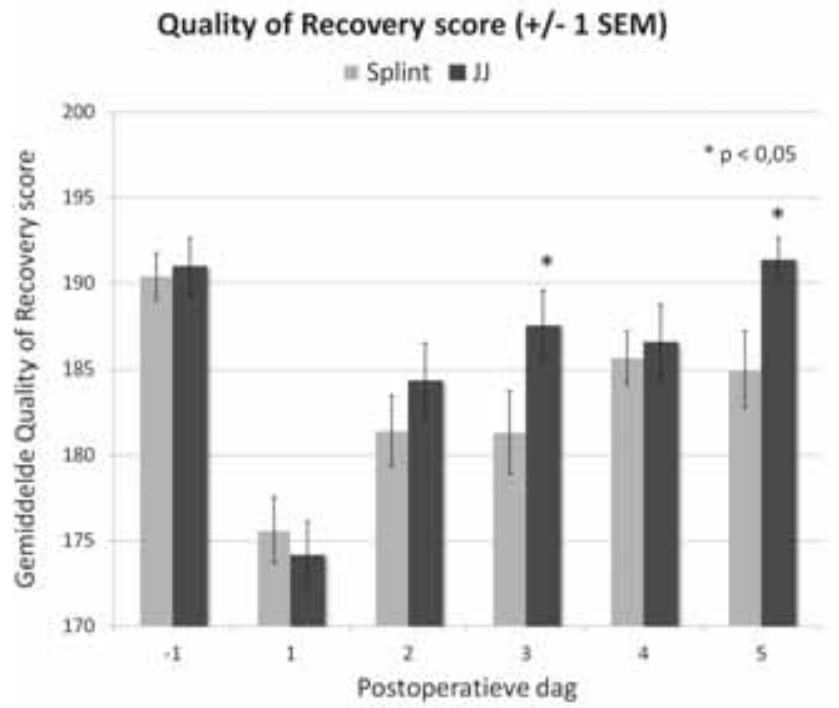

Figuur 13.1

deze groep werd de transurethrale katheter verwijderd op dag 5 postoperatief. Het vroege postoperatieve herstel werd dagelijks vervolgd door middel van vragenlijsten tot de dag van ontslag. De primaire uitkomstmaat was de quality of recovery (QoR) score. De QoR-40-vragenlijst is een gevalideerde vragenlijst met een maximum van 200 punten, om het postoperatieve herstel te meten over verschillende categorieën (gevoelens, emoties, zelfredzaamheid, steun en pijn). Secundaire uitkomstmaten waren het bereiken van ontslagcriteria, opnameduur, complicaties en een blaasklachtenvragenlijst.

\section{Resultaten}

De gemiddelde QoR-40 scores op dag 5 postoperatief in de JJ-groep en de splintgroep waren resp. 191,3 $(\mathrm{SD}=8,0)$ en $185,0(\mathrm{SD}=13,9) ; p=0,02$. Dit wordt beoordeeld als een klinisch relevant verschil. Daarnaast bereikten de patiënten met de JJ-katheter eerder de ontslagcriteria en konden zij 1-2 dagen eerder met ontslag. Het aantal vroege urologische complicaties postoperatief was vergelijkbaar tussen de twee groepen. Er was geen verschil in blaasklachten tussen beide groepen.

\section{Conclusie}

Het gebruik van JJ-katheters tijdens levende-donorniertransplantaties, in vergelijking met splints, verbetert de kwaliteit van het vroege postoperatieve herstel en verkort de opnameduur. 


\section{Verwijden of verwijderen? De preputium- plastiek is een goed alternatief voor circumcisie}

\author{
M.J. te Dorsthorst, A.W.T.M. Roelofs, O.P.J. Vrooman en \\ M.R. van Balken \\ Rijnstate Ziekenhuis, Arnhem
}

\section{Introductie}

Phimosis is een vaak voorkomend probleem, in Nederland wordt de diagnose jaarlijks ongeveer 5.000 maal gesteld. Naast de conservatieve therapie middels corticosteroïdencrème zijn er meerdere chirurgische behandelingen mogelijk, waaronder de preputiumplastiek. Ondanks de goede resultaten die worden beschreven in de literatuur na een preputiumplastiek wordt het overgrote deel van de patiënten toch nog steeds behandeld middels een circumcisie, een interventie met hoger complicatierisico in de vorm van infectie, nabloeding, meatusstenose en psychologische problematiek.

\section{Materiaal en methoden}

Er werd middels een retrospectieve studie gekeken naar de resultaten van de preputiumplastieken van de afgelopen vijf jaar. Alle patiënten van 1-18 jaar die een preputiumplastiek hebben ondergaan, werden geïncludeerd. Er werd gekeken naar resultaten en complicaties binnen 90 dagen na de ingreep. Als complicaties werd infectie, re-chirurgische interventie of bloeding geteld. Complicaties werden gescoord volgens Clavien-Dindo.

\section{Resultaten}

In totaal werden er 70 patiënten geïncludeerd in de leeftijd van 1-18 jaar, mediane leeftijd was 11 jaar. 1 patiënt was lost to follow-up. Voorafgaand aan de chirurgische interventie had $88,6 \%$ een corticosteroïdencrème gebruikt met ontoereikend effect. Bij de eerste controle postoperatief was $69,6 \%$ direct tevreden. In 18,8\% van de gevallen was er nog

Tabel 14.1 Vóórkomen van complicaties en therapie-uitkomst binnen de onderzoeksgroep

\begin{tabular}{|c|c|c|}
\hline & $\begin{array}{l}\text { controlemoment } \\
\text { binnen } 30 \text { dagen }\end{array}$ & $\begin{array}{l}\text { controlemoment } \\
\text { binnen } 90 \text { dagen }\end{array}$ \\
\hline bloeding & $1,4 \%$ & - \\
\hline infectie & $4,3 \%$ & - \\
\hline re-chirurgische interventie & $2,9 \%$ & $2,9 \%$ \\
\hline $\begin{array}{l}\text { ontevreden over } \\
\text { cosmetisch resultaat }\end{array}$ & $2,9 \%$ & $2,9 \%$ \\
\hline $\begin{array}{l}\text { kortdurende cortico- } \\
\text { sterö̈dencrème }\end{array}$ & $18,8 \%$ & $8,7 \%$ \\
\hline $\begin{array}{l}\text { geen aanvullende } \\
\text { interventies meer nodig }\end{array}$ & $69,6 \%$ & $85,5 \%$ \\
\hline
\end{tabular}

een korte periode (4-6 weken) van corticosteroïdencrème nodig, waarna er een goed eindresultaat werd behaald op dag 90 postoperatief. In slechts twee gevallen (2,9\%) moest er opnieuw een chirurgische interventie plaatsvinden. Eén patiënt had een bloeding waarvoor conservatief beleid werd gevoerd. Uiteindelijk was $85,5 \%$ van de patiënten tevreden op dag 90 postoperatief en behoefde geen interventie meer (tabel 14.1).

\section{Conclusie}

Middels deze analyse willen we aantonen dat de preputiumplastiek een volwaardig alternatief is met een laag complicatierisico naast de reeds bestaande behandelingen van een phimosis.

\section{Superieure effectiviteit van neoadjuvante chemotherapie en radicale cystectomie in cT3-4NOMO blaascarcinoom ten opzichte van cT2N0M0 blaascarcinoom}

T.J.N. Hermans, C.S. Voskuilen, M. Deelen, L.S. Mertens,

S. Horenblas, R.P. Meijer, J.L. Boormans, K.K. Aben, M.S. van der Heijden, R. de Wit, L.V. Beerepoot, R.H.A. Verhoeven en B.W.G. van Rhijn

Nederlands Kanker Instituut, Amsterdam

\section{Introductie}

Huidige internationale richtlijnen adviseren neoadjuvante chemotherapie ( $n \mathrm{AC}$ ) bij het cT2-4aN0M0 blaascarcinoom (BC). Vanwege de beperkte overlevingswinst van 5-8\% na 10 jaar, de kans op toxiciteit en het ontbreken van predictieve markers voor respons bestaat er terughoudendheid omtrent het geven van NAC voorafgaand aan radicale cystectomie (RC). Anderzijds is een complete pathologische respons ( $\mathrm{pCR}$ ) geassocieerd met een zeer gunstige prognose. In deze studie vergeleken wij pCR $(\leq(\mathrm{y}) \mathrm{pT} 1 \mathrm{~N} 0)$ en algehele overleving (OS) bij cT2 versus cT3-4aN0M0 BC na $\mathrm{RC}$ zonder voorbehandeling en na neoadjuvante chemotherapie $(n \mathrm{AC}+\mathrm{RC})$.

\section{Materiaal en methoden}

Data van 5322 patiënten die tussen 1995 en 2013 RC of $\mathrm{NAC}+\mathrm{RC}$ ondergingen vanwege een cT2-4N0M0 urotheelcelcarcinoom van de blaas werden verkregen via de Nederlandse Kankerregistratie. Klinische gegevens werden gekoppeld aan gegevens uit de databank van het Pathologisch Anatomisch Landelijk Geautomatiseerd Archief (pALGA). pCR tussen beide groepen werd vergeleken middels de chi-kwadraattest. Middels Cox-regressieanalyse (leeftijd, geslacht, NAC en pelviene lymfeklierdissectie ( $\mathrm{pLND}$ )) werden hazard ratio's (HR) voor OS berekend. 


\section{Resultaten}

Wij includeerden 4355 (82\%) patiënten met cT2 (191 $\mathrm{NAC}+\mathrm{RC})$ en 967 (18\%) patiënten met cT3-4a BC (133 $\mathrm{NAC}+\mathrm{RC}$ ). De mediane follow-up was 9,2 jaar (IQR 5,8-14,0). Bij cT2 BC had 25\% van de RC-patiënten pCR, vs. $43 \%$ in de NAC+RC-groep $(p<0,001)$. Bij cT3-4a BC was dit het geval bij resp. $8 \%$ en $37 \%(p<0,001)$ van de patiënten. In de cT2groep was de vijfjaars-OS $51 \%$ na RC $v s$. $57 \%$ na NAC+RC $(p=0,135)(n \mathrm{NT}=17)$, terwijl deze in de cT3-4a-groep $36 \%$ vs. $55 \%$ was $(p<0,001)(n \mathrm{NT}=5)$. In de multivariate analyse was NAC geassocieerd met een betere OS bij cT3-4a BC (HR $=0,67 ; 95 \%-\mathrm{BI}=0,51-0,89)$, maar niet in cT2 $\mathrm{BC}(\mathrm{HR}=0,91$; $95 \%-\mathrm{CI}=0,72-1,15)$. In cT2 was PLND geassocieerd met een betere $\mathrm{OS}(\mathrm{HR}=0,88 ; 95 \%-\mathrm{CI}=0,78-0,99)$.

\section{Conclusie}

In een groot cohort van meer dan 5000 BC-patiënten gaf $\mathrm{NAC}+\mathrm{RC}$ vaker een pCR dan RC zonder NAC. Bij een lokaal uitgebreide tumor (cT3-4a) vertaalde dit zich in een significant betere vijfjaars-OS voor patiënten die met NAC waren behandeld.

\section{Verminderd seksueel welbevinden na Sachse- urethrotomie, ongeacht of er intermitterend katheteriseren wordt toegepast}

\author{
M. Westgeest, E.C. Goosen en M.R. van Balken \\ Rijnstate Ziekenhuis, Arnhem
}

\section{Introductie}

$\mathrm{Na}$ een Sachse-urethrotomie is er een hoge kans op een recidiefstrictuur, waardoor het vaak nodig is om hierna intermitterend te katheteriseren (CIC). Het doel van deze studie is om te onderzoeken of er een verschil bestaat in seksueel welbevinden tussen patiënten die wel en niet CIC toepassen na een Sachse.

\section{Materiaal en methoden}

Een retrospectief statusonderzoek werd verricht bij patiënten (141) die tussen 2010 en 2014 een Sachse ondergingen. De International Index of Erectile Function (IIEF) vragenlijst werd afgenomen, bestaande uit: 'Erectiele functie' (EF), 'Orgastische functie' (OF), 'Seksuele verlangens' (SV), 'Tevredenheid geslachtsgemeenschap' (TG) en 'Algehele tevredenheid' (AT) met scores van 0-10 (OF, SV, AT), 0-15 (TG) en 0-30 (EF), waarbij een hogere score overeenkomt met een beter seksueel welbevinden. Bij de Male Sexual Health Questionnaire for Ejaculatory Dysfunction (MSHQ-EjD), met scores van 1-20, komt een hogere score overeen met beter functioneren van ejaculatie. Responspercentage was 36\%. Statistische analyse werd uitgevoerd met een ongepaarde $t$-test (SPSS 22).
Tabel 16.1

\begin{tabular}{llll}
\hline & CIC & geen CIC & literatuur \\
\hline IIEF - Erectiele functie & $13,8 \pm 7,5$ & $11,7 \pm 7,8$ & 25,8 \\
IIEF - Orgastische functie & $3,7 \pm 8,1$ & $3,1 \pm 3,6$ & 9,8 \\
IIEF - Seksuele verlangens & $6,7 \pm 1,8$ & $7,8 \pm 2,6$ & 7,0 \\
IIEF - Tevredenheid & $3,4 \pm 3,8$ & $2,2 \pm 3,2$ & 10,6 \\
$\quad$ geslachtsgemeenschap & & & \\
IIEF - Algehele tevredenheid & $6,0 \pm 3,2$ & $5,6 \pm 3,2$ & 8,6 \\
MSHQ-EjD & $8,7 \pm 4,1$ & $6,9 \pm 4,3$ & 16,8 \\
\hline
\end{tabular}

\section{Resultaten}

54 patiënten werden geïncludeerd met een gemiddelde leeftijd van $64 \pm 15,6$ jaar. Bij 59,3\% van de patiënten was CIC noodzakelijk. Dit komt overeen met de literatuur (40-65\%). $\mathrm{Na}$ een follow-up van 3,2 $\pm 1,5$ jaar, was er geen verschil in de vijf domeinen van de IIEF tussen CIC en niet-CIC. EF = $13,8 \pm 7,5 v s .11,7 \pm 7,8(p=0,388), \mathrm{OF}=3,7 \pm 8,1$ vs. 3,1 $\pm 3,6(p=0,593), \mathrm{SV} 6,7 \pm 1,8 v s .7,8 \pm 2,6(p=0,317)$, $\mathrm{TG}=3,4 \pm 3,8 v s .2,2 \pm 3,2(p=0,308)$ en $\mathrm{AT}=6,0 \pm 3,2 v s$. $5,6 \pm 3,2(p=0,738)$. De MSHQ-EjD-scores waren 8,7 \pm 4,1 vs. $6,9 \pm 4,3(p=0,202)$. In vergelijking met de literatuur (mannen zonder mictieklachten, gem. leeftijd 57 jaar) is er een verminderd seksueel welbevinden (zie tabel 16.1).

\section{Conclusies}

In dit onderzoek is intermitterend katheteriseren na Sachseurethrotomie niet geassocieerd met verminderde seksuele functie, wanneer deze wordt gemeten met de IIEF en de MSHQ-EjD vergeleken met niet-katheteriseren. In vergelijking met de literatuur is er wel afname van seksueel welbevinden na urethrastrictuurchirurgie.

\section{Circulerende tumorcellen in niet-gemetasta- seerd spierinvasief blaascarcinoom: interim resul- taten van de CirGuidance studie}

I.E. de Kruijff, N. Beije, R. Jacobs, P. de Vries, O.S. Klaver, R.M. Somford, Prof. F. Witjes, J.H. KleinJan, H.H.E. van Melick, P.J. Ausems, W.H. Hirdes, C.J. Wijburg, L.M.C.L. Fossion, E.R. Boevé, B.P. Wijsman, E.C. Timmer, M.J.B. Aarts, B.T. Merks, Prof. R. de Wit, Prof. S. Sleijfer en J.L. Boormans Erasmus MC Kanker Instituut, Rotterdam

\section{Introductie}

De standaardbehandeling voor patiënten met niet-gemetastaseerd spierinvasief blaascarcinoom (SIBC) is radicale cystectomie. Cisplatin-bevattende neoadjuvante chemotherapie $(n \mathrm{AC})$ voorafgaand aan cystectomie geeft een overlevingswinst van $6 \%$ na 10 jaar. Vanwege deze beperkte winst en de eventuele toxiciteit van NAC, is een biomarker 
die correleert met de respons op NAC zeer relevant. De CirGuidance-studie onderzoekt of circulerende tumorcellen (CTC's) kunnen sturen in de beslissing om wel of geen NAC te geven voorafgaand aan radicale cystectomie. Hier rapporteren wij de correlatie tussen CTC-status en standaard klinische en pathologische karakteristieken bij 230 geïncludeerde patiënten.

\section{Materiaal en methoden}

Patiënten met een T2-T4aN0-1M0 urotheelcelcarcinoom van de blaas werden geïncludeerd in 16 Nederlandse centra. $\mathrm{Na}$ inclusie werd een CTC-telling verricht met het CellSearch ${ }^{\circledR}$-systeem, inclusief een HER2-kleuring. Patiënten bij wie geen CTC's detecteerbaar waren, ondergingen direct radicale chirurgie. CTC-positieve patiënten kregen het advies: NAC gevolgd door radicale chirurgie. CTC-status (aan- vs. afwezig) werd gecorreleerd met klinische en pathologische parameters middels de chi-kwadraattoets. De studie is goedgekeurd door de medische ethische commissie (METC-2013-301).

\section{Resultaten}

De gemiddelde leeftijd was 68 jaar (range 43-85) en in 56 van de 230 (24\%) gevallen werd één of meer CTC's gevonden. Hiervan had 27\% een of meer HER2-positieve CTC's. Er was geen correlatie tussen klinische of pathologische karakteristieken en CTC-status (zie tabel 17.1). De gemiddelde overleving van de eerste 100 patiënten na twee jaar follow-up was 25 maanden (range 1-46).

\section{Conclusie}

CTC's zijn te detecteren bij 1 op de 4 SIBC-patiënten voorafgaand aan radicale cystectomie. Wij vonden geen correlatie tussen CTC-status en klinische of pathologische karakteristieken. CTC's lijken daarom een onafhankelijke marker bij SIBC, waarvan de prognostische waarde nog definitief moet worden bewezen.

Funding: Erasmus MC Medical research advisory committee (Mrace).

Tabel 17.1

\begin{tabular}{lll}
\hline & aantal & chi-kwadraattoets \\
\hline man:vrouw & $2,5: 1$ & $p=0,47$ \\
cT-stadium & $76 \% \leq \mathrm{cT} 2 / 24 \%>$ cT2 & $p=0,38$ \\
pT-stadium & $53 \%>(\mathrm{y}) \mathrm{pT} 2$ & $p=0,13$ \\
N-stadium & $26 \%$ & $p=0,95$ \\
prostaatkanker & $26 \%$ van de mannen & $p=0,58$ \\
\hline
\end{tabular}

\section{Radiotherapie en EGFR-inhibitie na lymfeklierdissectie en inductiechemotherapie voor invasieve blaaskanker}

E.E. Fransen van de Putte, F.J. Pos, V. van der Noort, B. Doodeman, B.W.G. van Rhijn, J. Bloos-van der Hulst, E. van der Laan, M.S. van der Heijden, J.M. Kerst, S. Horenblas en A.M. Bergman

Antoni van Leeuwenhoek, Amsterdam

\section{Introductie}

Voor patiënten met invasieve blaaskanker (BC) is radiotherapie (RT) een orgaansparend alternatief voor cystectomie en lymfeklierdissectie (PLND), met name bij een matige conditie. Gerapporteerde uitkomsten van RT alleen zijn echter inferieur. Overexpressie van epidermale groeifactorreceptor (EGFr) bij $\mathrm{BC}$ is geassocieerd met radioresistentie. Met deze studie onderzochten wij de veiligheid en effectiviteit van RT, gecombineerd met de EGFr-antagonist panitumumab (RT/P) bij BC. Voor RT/P ondergingen patiënten een PLND en neoadjuvante/inductie chemotherapie (nAIC).

\section{Materiaal en methoden}

Geïncludeerd werden cT2-4N0-2M0- of cT1N1-2M0 BCpatiënten. cN0-patiënten kregen vier cycli platinumgebaseerde NAC na PLND. cN+-patiënten (bevestigd met cytologische biopten) kregen NAIC voor PLND. RT/P bestond uit zeven wekelijkse doses $2,5 \mathrm{mg} / \mathrm{kg}$ panitumumab in combinatie met 66Gy RT in 33 fracties. Primaire uitkomstmaten waren toxiciteit (afkapwaarde non-inferieur aan RT/cisplatine, $<35 \%$ graad 3-4-toxiciteit), complete klinische respons (CR) (CT en cystoscopie na 3 maanden follow-up) en cystectomievrije overleving.

\section{Resultaten}

Initieel werden 38 patiënten geïncludeerd, van wie $34 \mathrm{cN} 0$ BC hadden. Na PLND werden 7/34 (21\%) patiënten $\mathrm{pN}+$ bevonden. RT/P werd gestart bij 31/38 patiënten. Gedurende RT/P hadden vijf patiënten $(16 \%$; 95\%-CI $=0-31)$ systemische of locale graad 3-4-toxiciteit. Vier patiënten hebben de behandeling niet afgemaakt door bijwerkingen. 29/31 patiënten (94\%; 95\%-CI = 83-100) hadden een CR. Bij een mediane follow-up van 34 maanden hadden vier (13\%) patiënten een locaal recidief, drie (10\%) patiënten ondergingen een salvagecystectomie.

\section{Conclusie}

RT/P na NAIC en PLND heeft een non-inferieure toxiciteit aan cisplatine/RT. Het hoge complete respons- en blaaspreservatiepercentage is veelbelovend. 


\section{De betrouwbaarheid van de meting in Houns- field Units van stenen in de urinewegen}

G.W. Disselhorst, R.K. van der Vijgh, R.A.F.J. Sandkuyl,

J.J. Reimerink en E.P. van Haarst

OLVG, Amsterdam

\section{Introductie}

Bij urologen en radiologen wordt mogelijk een grote variatie gezien in de meting van hardheid van stenen in de urinewegen op non-contrast computed tomography (NCCT). De hardheid, gemeten in Hounsfield Units (HU), is een belangrijke steenkarakteristiek die van invloed is op behandelkeuze en -succes. Het doel van deze studie is de betrouwbaarheid van de HU-meting van stenen in de urinewegen op NCCT te onderzoeken.

\section{Materiaal en methoden}

Alle NCCT ( $n=1.006)$ gemaakt volgens niersteenprotocol tussen 31 december 2013 en 1 augustus 2016 zijn retrospectief verkregen en geanonimiseerd. Op basis van powerberekening zijn 155 NCCT-scans van 143 patiënten geïncludeerd met stenen van $\geq 4 \mathrm{~mm}$ diameter. In vier ronden werden door vijf beoordelaars ( 2 radiologen, 1 aios radiologie, 1 uroloog, 1 aios urologie) alle geïncludeerde NCCT's beoordeeld. In ronde 1 en 2 werd er geen instructie voor de HU-meting gegeven. In ronde 3 en 4 werd volgens opgesteld protocol gemeten (o.a. 3 axiale vlakken, botsetting). De overeenkomst van de HU-waarde tussen de vijf beoordelaars (inter) en voor elke beoordelaar tussen twee beoordelingen (intra) werd berekend door gebruik te maken van de intraclass-correlatiecoëfficiënt (ICC), Fleiss kappa (K) en Cohen's kappa (K). Voor de kappatest werd de HU omgezet van een continue naar een binomiale variabele van $<1000 \mathrm{HU}$ en $>1000 \mathrm{HU}$, corresponderend met wel of niet geschikt voor ESWL. Voor de analyses van ronde 3 en 4 werd het gemiddelde van de drie vlakken gebruikt.

\section{Resultaten}

De interbeoordelaarsovereenkomst in ronde 1 was de ICC $=$ $0,82(95 \%$-CI $=0,76-0,86)$; Fleiss $\mathrm{K}=0,66$ en in ronde 3 was de ICC 0,60 (95\%-CI =0,33-0,75); Fleiss $\mathrm{K}=0,38$. Intrabeoordelaarsovereenkomst: tussen ronde 1 en ronde 2 was de ICC 0,87; Cohen's K =0,74; en tussen ronde 3 en 4 was de ICC 0,87; Cohen's K =0,68.

\section{Conclusie}

Zowel de inter- als intrabeoordelaars-ICC en $\mathrm{K}$ van de meting zonder instructie indiceren een goede overeenkomst. Vanwege de klinische consequentie van de gemeten $\mathrm{HU}$ is echter een hogere overeenkomst (ICC en met name K) wenselijk. Ondanks onze verwachting geeft meten volgens protocol geen verbetering van de betrouwbaarheid van de HU-meting.

\section{Partiële of radicale cystectomie voor intra- diverticulair blaascarcinoom: een internationale multicenteranalyse}

\author{
C.S. Voskuilen, R. Seiler, M. Rink, C. Poyet, A.P. Noon, \\ F. Roghmann, A. Necchi, A. Aziz, A. Lavollé, M.J. Young, \\ P. Marks, K. Saba, B.W.G. van Rhijn, E.E. Fransen van de Putte, \\ J. Ablat, P.C. Black, J. Dobruch, J.W.F. Catto, E. Xylinas en \\ K. Hendricksen \\ Antoni van Leeuwenhoek, Amsterdam
}

\section{Introductie}

Het intradiverticulair blaascarcinoom (IDBC) is zeldzaam en de huidige kennis over IDBC is ontoereikend voor een risicogeadapteerde behandeling. Wij onderzochten in een multicenter cohort de klinische en pathologische karakteristieken van IDBC en vergeleken oncologische uitkomsten na radicale $(\mathrm{RC})$ en partiële cystectomie (PC).

\section{Materiaal en methoden}

Data van patiënten die tussen 1995 en 2017 behandeld werden voor IDBC werden verzameld vanuit databases in tien centra. Klinisch tumorstadium (cT) op basis van diagnostische transurethrale resectie (TUR) werd vergeleken met het pathologisch tumorstadium op basis van RC/PC (pT). Overall (OS) en recidiefvrije overleving (RFS) na $\mathrm{RC}$ en $\mathrm{PC}$ werden vergeleken. In een multivariabel Cox-regressiemodel voor OS werd gecorrigeerd voor leeftijd, neoadjuvante chemotherapie, pT en snijvlakstatus.

\section{Resultaten}

We includeerden 113 (108 mannen) patiënten met een mediane leeftijd van 71 jaar (range 39-89). Mediane follow-up was 5,1 jaar (95\%-BI = 3,8-6,3). Tumorstadium was cTa/is, cT1 en $\geq$ cT2 bij resp. $8(7 \%), 65(58 \%)$ en 40 (35\%) patiënten. Zes patiënten (5\%) ondergingen alleen TUR, terwijl resp. 81 (72\%) en $26(23 \%)$ patiënten $\mathrm{RC}$ en $\mathrm{PC}$ ondergingen. In de PC-groep ondergingen 11/26 patiënten tevens brachytherapie. Bij 38/65 (58\%) van de patiënten met cT1 BC bleek sprake van een $\geq$ pT2-tumor bij PC/RC. Er waren geen statistisch significante verschillen in klinicopathologische kenmerken tussen de RC- en PC-groep. Driejaars-OS en RFS waren vergelijkbaar na $\mathrm{RC}$ en $\mathrm{PC}(\mathrm{OS}=67 \%$ vs. 66\%; $p=0,58 ; \operatorname{RFS}=64 \%$ vs. $59 \% ; p=0,23)$. In multivariabele analyse waren snijvlakstatus en pT significante voorspellers voor OS, behandeling ( $\mathrm{RC}$ vs. $\mathrm{PC})$ was dat niet $(\mathrm{HR}=1,03$ $(95 \%-\mathrm{BI}=0,50-2,11) ; p=0,53)$.

\section{Conclusie}

Het is belangrijk te beseffen dat bij IDBC vaak (58\%) sprake is van onderstadiëring. Overleving na PC en RC is vergelijkbaar, ook na correctie voor tumorstadium. PC kan een oncologisch veilige behandeling zijn voor geselecteerde IDBC-patiënten. 


\section{Injectie van bulkmateriaal bij de behandeling van postprostatectomie-urine-incontinentie: een pilotstudie naar veiligheid en effectiviteit}

J.I.M. van Uhm, M. Vermeer, H.W. Elzevier, J.W. Noordzij,

E.L. Koldewijn en E.B. Cornel

Leids Universitair Medisch Centrum, Leiden

\section{Introductie}

Urinaire stressincontinentie (SUI) na radicale prostatectomie heeft een grote invloed op de kwaliteit van leven. In deze studie werden de veiligheid en effectiviteit van een minimaal invasieve behandeling middels transurethrale bulkinjecties bij patiënten met minimale urine-incontinentie geëvalueerd.

\section{Materiaal en methoden}

10 patiënten met SUI ( $<30$ gram/24 uur) na radicale prostatectomie ondergingen endoscopische transurethrale, pre-sfincterische, submucosale injecties met bulkmateriaal. De interventie werd geëvalueerd na één, drie en zes maanden. De primaire uitkomst was het gewogen urineverlies in inleggers/24 uur. Succes werd gedefinieerd als $<3$ g verlies/ 24 uur, verbetering als $\geq 50 \%$ vermindering in verlies/24 uur, falen als $<50 \%$ verbetering in verlies $/ 24$ uur. De secundaire uitkomsten werden gemeten middels gevalideerde vragenlijsten: de International Consultation on Incontinence Questionnaire Short Form (ICIQ-SF), de Incontinence Impact Questionnaire (IIQ-7), de Urogenital Distress Inventory Short Form (UDI-6-SF) en de Patient Global Impression of Improvement (pGI-I).

\section{Resultaten}

$\mathrm{Na}$ één maand was er bij één patiënt sprake van succes, bij één patiënt van verbetering en bij acht patiënten van falen. $\mathrm{Na}$ drie en zes maanden was er bij één patiënt sprake van verbetering en bij negen patiënten van falen. Eén, drie en zes maanden na de injectie was de mediane hoeveelheid urineverlies gemeten in inleggers/24 uur hoger dan voor de injectie (tabel 21.1). De ICIQ-SF was verhoogd na drie en zes maanden. Er waren geen verschillen in de uitkomsten, gemeten met de IIQ-7, de UDI-6-SF en de PGI-I-vragenlijsten voor en na injectie. Vier patiënten hadden een Clavien-Dindo-complicatie klasse 1, spontaan gestopte hematurie en frequency.

\section{Conclusie}

Injectietherapie met bulkmateriaal lijkt niet veilig en effectief bij de behandeling van SUI na radicale prostatectomie.

Tabel 21.1 Resultaten

\begin{tabular}{|c|c|c|c|c|c|c|c|}
\hline & voor injectie & $\begin{array}{l}1 \text { maand } \\
(n=10)\end{array}$ & $p$ & $\begin{array}{l}3 \text { mnd } \\
(n=10)\end{array}$ & $p$ & $\begin{array}{l}6 \text { mnd } \\
(n=10)\end{array}$ & $p$ \\
\hline \multicolumn{8}{|c|}{ behandelingsuitkomst, $n(\%)$} \\
\hline succes & & $1(10)$ & & $0(0)$ & & $0(0)$ & \\
\hline verbetering & & $1(10)$ & & $1(10)$ & & $1(10)$ & \\
\hline falen & & $8(80)$ & & $9(90)$ & & $9(90)$ & \\
\hline \multicolumn{8}{|c|}{ 24-uursgewicht in inleggers $(\mathrm{g})$ mediaan (IQR) } \\
\hline & $\begin{array}{l}17,3 \\
(6,4-20,9)\end{array}$ & $\begin{array}{l}40,3 \\
(5,9-130,6)\end{array}$ & 0,038 & $\begin{array}{l}38,3 \\
(18,3-202,1)\end{array}$ & 0,014 & $\begin{array}{l}55,0 \\
(16,5-314,6)\end{array}$ & 0,028 \\
\hline \multicolumn{8}{|c|}{ ICIQ-SF-score, mediaan (IQR) } \\
\hline & $\begin{array}{l}10,0 \\
(9,0-12,0)\end{array}$ & $\begin{array}{l}16,0 \\
(11,8-18,0)\end{array}$ & 0,109 & $\begin{array}{l}15,0 \\
(12,0-18,5)\end{array}$ & 0,007 & $\begin{array}{l}16,0 \\
(12,5-17,5)\end{array}$ & 0,012 \\
\hline \multicolumn{8}{|c|}{ IIQ-7-score, mediaan (IQR) } \\
\hline & $\begin{array}{l}26,5 \\
(13,0-41,5)\end{array}$ & $\begin{array}{l}38,0 \\
(34,5-50,3)\end{array}$ & 0,122 & $\begin{array}{l}49,5 \\
(17,8-67,0)\end{array}$ & 0,413 & $\begin{array}{l}36,0 \\
(15,5-62,0)\end{array}$ & 0,528 \\
\hline \multicolumn{8}{|c|}{ UDI-6-SF-score, mediaan (IQR) } \\
\hline & $\begin{array}{l}33,0 \\
(20,8-40,3)\end{array}$ & $36,0(26,5-44,0)$ & 0,553 & $\begin{array}{l}39,0 \\
(17,0-58,5)\end{array}$ & 0,552 & $\begin{array}{l}39,0 \\
(28,0-47,0)\end{array}$ & 0,766 \\
\hline \multicolumn{8}{|c|}{ PGI-I-score, mediaan (IQR) } \\
\hline & $\mathrm{g}, \mathrm{v}, *$ & $\begin{array}{l}5,5 \\
(4,8-6,0)\end{array}$ & 0,102 & $\begin{array}{l}4,5 \\
(3,8-6,0)\end{array}$ & 0,121 & $\begin{array}{l}5,0 \\
(3,5-5,0)\end{array}$ & 0,206 \\
\hline
\end{tabular}

p-waarde correspondeert met de Wilcoxon signed-ranktest voor beoordeling van de data voor injectie d.d. één, drie en zes maanden na injectie. g.v. = geen verandering; voor statistische analyse hebben we een uitgangswaarde aangenomen van 4. 


\section{Blaassparende behandeling met brachythera- pie voor blaascarcinoom: langetermijnresultaten en vergelijking met radicale cystectomie in een multicenter setting}

C.S. Voskuilen, J. Bosschieter, E. van Werkhoven, K. Hendricksen, A.N. Vis, F.J. Pos, B.R. Pieters, L. Moonen, S. Horenblas, J.A. Nieuwenhuijzen en B.W.G. van Rhijn Antoni van Leeuwenhoek, Amsterdam

\section{Introductie}

Voor patiënten met een solitair cT1G3-T2N0M0 blaascarcinoom $(\mathrm{BC})<5 \mathrm{~cm}$ kan blaassparende behandeling middels brachytherapie in combinatie met uitwendige radiotherapie (BT) een alternatief zijn voor radicale cystectomie (RC). BT voor BC blijft echter controversieel vanwege angst voor inferieure overlevingscijfers, blaasrecidieven en late toxiciteit. Wij onderzochten de langetermijnresultaten van BT voor $\mathrm{BC}$ en vergeleken deze met de uitkomsten van $\mathrm{RC}$.

\section{Materiaal en methoden}

Tussen 1988 en 2016 ondergingen 310 patiënten BT van de blaas in twee centra. Patiënten met histologie anders dan urotheelcarcinoom en tumorstadium $>$ cT2 werden geëxcludeerd. Overall (OS) en ziektespecifieke (DSS) overleving werden vergeleken met OS en DSS van gematchte patiënten die in dezelfde periode RC ondergingen. Exclusiecriteria in de RC-groep waren behandeling met neoadjuvante chemotherapie, carcinoma in situ of een tumor $>5 \mathrm{~cm}$. In een multivariaat Cox-regressiemodel werd gecorrigeerd voor geslacht, leeftijd, cT-stadium en tumorgrootte. Complicaties na BT en wel of geen blaasbehoud werden geregistreerd.

\section{Resultaten}

We includeerden 268 BT- en 161 RC-patiënten. Mediane follow-up was 10 jaar (95\%-BI =9,3-10,7). In de BT-groep hadden meer patiënten een cT2-tumor (90\% vs. $73 \%$ in de RC-groep, $p<0,001)$. In de RC-groep had 62\% van de patiënten multipele tumoren, in de BT-groep $0 \%(p<0,001)$. De vijf- en tienjaars-OS waren vergelijkbaar: $65 \% / 49 \%$ na BT en $63 \% / 42 \%$ na RC ( $p=0,25)$. Ook vijf- en tienjaars DSS waren vergelijkbaar: $71 \% / 63 \%$ na BT en $66 \% / 55 \%$ na $\mathrm{RC}$ $(p=0,15)$. In multivariate analyse waren leeftijd en tumorgrootte significante voorspellers voor OS. Er was geen significant verschil in OS tussen de BT- en de RC-groep (HR = $0,87(95 \%-\mathrm{BI}=0,65-1,18), p=0,39)$. Na BT ontwikkelden $48(18 \%)$ patiënten late toxiciteit, waarbij LUTS het meeste voorkwam $(n=16)$. Blaasbehoud was mogelijk in $87 \%$.

\section{Conclusie}

Voor zorgvuldig geselecteerde BC-patiënten is BT een veilige en effectieve behandeling. DSS en OS zijn vergelijkbaar met de gouden standaard (RC). Ernstige late toxiciteit is zeldzaam en blaasbehoud is mogelijk in het overgrote deel van de patiënten.

\section{Intravesicale chemohyperthermie als be- handeling voor patiënten met niet-spierinvasief blaascarcinoom (NSIBC) die niet reageren op BCG-blaasspoelingen}

\author{
J.J. de Jong, K. Hendricksen, M. Rosier, H. Mostafid en \\ J.L. Boormans \\ Erasmus MC Kanker Instituut, Rotterdam
}

\section{Introductie}

Intravesicale spoelingen met $\mathrm{BCG}$ verlagen het risico op een recidief bij patiënten met intermediair en hoogrisico niet-spierinvasief blaascarcinoom (NSIBC). Indien een patiënt, ondanks adequate BCG-behandeling, een recidief blaascarcinoom krijgt, wordt een radicale cystectomie geadviseerd. Hier presenteren wij de resultaten van intravesicale spoelingen met chemohyperthermie (CHT) als blaassparend alternatief voor NSIBC-patiënten die niet reageren op BCG-blaasspoelingen.

\section{Materiaal en methoden}

Prospectief zijn tussen 2014 en 2018 in drie centra (Rotterdam, Amsterdam en Guildford) data verzameld van patiënten die werden behandeld met chemohyperthermie in verband met NSIBC. Patiënten werden alleen geïncludeerd in deze studie als zij volgens de recent gepubliceerde definitie van de International Bladder Cancer Network 'ongevoelig voor BCG' waren en $\geq 5$ CHT-spoelingen ondergingen. Chemohyperthermie bestond uit een inductie- en een onderhoudsfase. Patiënten werden driemaandelijks gevolgd met cystoscopie en cytologie en jaarlijks met een CT van de urinewegen. Het primaire eindpunt was de recidiefvrije overleving (RVO). De toxiciteit werd vastgelegd middels de Common Terminology Criteria for Adverse Events (CTCAE).

\section{Resultaten}

In totaal werden 54 patiënten (47 mannen, 7 vrouwen, \pm 71 jaar) met intermediair (TaG2; 7\%) en hoogrisico (Ta/T1G3/ CIS; 93\%) NSIBC, die niet reageerden op BCG-blaasspoelingen, behandeld met $\geq 5$ CHT-spoelingen. De mediane follow-up was 15,3 maanden $(\mathrm{IQR}=8,7-25,2)$ en in $54 \%$ van de gevallen trad er een recidief op. De mediane RVO was 13,1 maanden $(\mathrm{SE}=2,43)$. Van de 31 patiënten met (bijkomend) CIS kreeg 55\% een recidief en was de mediane RVO ook 13,1 maanden $(\mathrm{SE}=5,20)$. Drie patiënten vertoonden progressie tot spierinvasief blaaskanker en twee patiënten ervaarden hevige bijwerkingen van de chemohyperthermie (CTCAE > 2). 


\section{Conclusie}

Chemohyperthermie resulteerde in een RVO $>1$ jaar bij NSIBC-patiënten die niet reageren op BCG blaasspoelingen en stelt mogelijk de noodzaak van een radicale cystectomie uit.

\section{Effectiviteit percutane tibiale nerve stimulatie (PTNS) bij kinderen.}

\author{
L.L. de Wall, J.G.L. Cobussen-Boekhorst, M. Trompetter en \\ B.B.M. Kortmann \\ Radboudumc Amalia Kinderziekenhuis, Nijmegen
}

\section{Introductie}

Overactieve blaas $(\mathrm{OAB})$ met of zonder urine-incontinentie is een veel voorkomende aandoening bij schoolgaande kinderen. Standaardbehandelingen, zoals urotherapie, psychologische ondersteuning en medicamenteuze therapie hebben bij $20 \%$ van de patiënten onvoldoende resultaat. Percutaneous tibial nerve stimulation (PTNS) is een behandelingsoptie die bewezen effectief is voor volwassenen met $\mathrm{OAB}$, maar nog onvoldoende is onderzocht in kinderen. In deze studie worden de uitvoerbaarheid en het effect van PTNS in kinderen onderzocht.

\section{Materiaal en methoden}

Prospectieve, observationele, exploratieve studie in kinderen met therapieresistente $\mathrm{OAB}$. Alle kinderen ondergingen een schema van 12 wekelijkse PTNS-behandelingen met nadien een afbouwschema indien er een positief effect werd behaald. De primaire uitkomstparameter was verschil in frequentie en mate van urine-incontinentie geclassificeerd volgens de richtlijnen van de International Children's Continence Society. Secundaire uitkomstparameters waren verschil in mate van urgency, dagfrequentie, gemiddelde en maximale blaascapaciteit (gecorrigeerd voor de verwachte capaciteit voor de leeftijd).

\section{Resultaten}

In totaal werden 20 kinderen met een gemiddelde leeftijd van 9,7 jaar behandeld. Een complete respons (100\% reductie in incontinentie) werd behaald bij negen patiënten (45\%), een partiële respons (50-99\% reductie in incontinentie) bij zeven patiënten $(35 \%)$ en bij vier patiënten $(20 \%)$ was er geen respons (0-49\% reductie in incontinentie). Er was geen significant verschil in mate van urgency, dagfrequentie en maximale blaascapaciteit gedurende de studie. Het gemiddeld geplaste volume per keer nam wel significant toe ( $p=$ $0,03)$ evenals de kwaliteit van leven $(p=0,0002)$. Er waren geen bijwerkingen of drop-outs ten gevolge van prikangst tijdens de studie.

\section{Conclusie}

PTNS is goed uitvoerbaar en heeft een overall effect van $80 \%$ bij kinderen met therapieresistente OAB.

\section{Keuzehulp voor patiënten die voor de keuze staan van een stoma of een neoblaas na cystecto- mie (www.stomaofneoblaas.nI)}

\author{
J.J. van Tol-Geerdink, D.M. Somford, C. Wijburg, \\ A.G. van der Heijden en J.A. Witjes \\ Radboudumc, Nijmegen
}

\section{Introductie}

$\mathrm{Na}$ cystectomie staan veel patiënten voor de keuze: stoma of neoblaas. Er is vooralsnog geen beste behandeling aan te wijzen. De behandelkeuze wordt nu vaak bepaald door de arts. Zo wordt er bijvoorbeeld vaker een stoma gekozen in laagvolumeziekenhuizen, bij kwetsbare patiënten en bij vrouwen. In deze beslissing zou echter duidelijker de voorkeur van de patiënt moeten worden meegewogen, zoals ook de richtlijn aanbeveelt. Hiertoe is een digitale keuzehulp ontwikkeld, waarin voor- en nadelen van de behandelingen overzichtelijk op een rij worden gezet. Patiënten worden daarbij gestimuleerd om te bedenken welke aspecten voor hen het zwaarst wegen.

\section{Methode}

Bij de ontwikkeling van de keuzehulp werden urologen, verpleegkundigen en patiënten betrokken. De keuzehulp werd getest in een pilotstudie met patiënten die een cystectomie ondergingen, en geëvalueerd met behulp van vragenlijsten. Kennis en rol in de besluitvorming werden vergeleken tussen patiënten met keuzehulp (KHgroep) en een controlegroep zonder keuzehulp (Cgroep).

\section{Resultaten}

Van de 47 benaderde patiënten gaven 41 informed consent $(87 \%)$ en werden 37 vragenlijsten ontvangen: 12 in de $\mathrm{C}$-groep en 25 in de $\mathrm{KH}$-groep. Van de kennisvragen werd in de C-groep 83\% correct beantwoord vs. 96\% in de KHgroep $(p=0,066)$. In de C-groep gaf $25 \%$ aan dat 'vooral of alleen' de arts de beslissing had genomen, tegenover $0 \%$ in de KH-groep $(p=0,011)$. Patiënten waren positief over de inhoud van de keuzehulp. Allen gaven aan dat er zelden of nooit onbegrijpelijke woorden in stonden en dat voor- en nadelen van stoma en neoblaas evenwichtig werden gepresenteerd. Patiënten ontvingen de keuzehulp op de dag van het diagnosegesprek (38\%), een dag tot een week erna $(19 \%)$ of later $(43 \%)$. Tevredenheid met de timing varieerde tussen die momenten (resp. $88 \%, 100 \%$ en $33 \%$ tevreden, $p=0,018)$. 


\section{Conclusie}

De keuzehulp werd positief beoordeeld en zorgde ervoor dat alle patiënten actief deelnamen aan de keuze. Uitreiken op de dag van diagnose komt voor de meeste patiënten niet te vroeg, terwijl uitreiken na meer dan een week voor de meesten wel ongewenst laat is.

\section{Diep neuromusculair blok tijdens laparo- scopische donornefrectomie reduceert vroege postoperatieve pijn}

M.H.D. Bruintjes, P. Krijtenburg, G.J. Scheffer, A. Dahan, C.H. Martini, F.C.H. d'Ancona, J.F. Langenhuijsen,

L.B. Hilbrands, A.E. Braat en M.C. Warlé

Radboudumc, Nijmegen

\section{Introductie}

Het gebruik van een diep neuromusculair blok tijdens laparoscopische ingrepen leidt tot een betere kwaliteit van het chirurgisch werkveld. Eveneens zijn er meerdere studies die een positief effect aantonen van diepe spierverslapping op postoperatieve pijnklachten. In deze studie wilden we onderzoeken of het gebruik van diepe spierverslapping ook de kwaliteit van het vroege postoperatieve herstel na levende nierdonatie verbetert.

\section{Materiaal en methoden}

In deze gerandomiseerde multicenter studie werden in totaal 96 patiënten, gepland voor laparoscopische donornefrectomie, verdeeld over een groep met een diep neuromusculair blok (groep A) en een groep met een standaard neuromusculair blok (groep B). In groep A werd na een initiële bolus rocuronium gestart met continue infusie van rocuronium, in tegenstelling tot groep B, waar na de initiële bolus enkel op verzoek van de chirurg een extra bolus rocuronium werd gegeven. De primaire uitkomstmaat was de Quality of Recovery (QoR) score. The QoR-40-vragenlijst is een gevalideerde vragenlijst met een maximum van 200 punten om het postoperatieve herstel te meten over verschillende categorieën (gevoelens, emoties, zelfredzaamheid, steun en pijn). Secundaire uitkomstmaten waren postoperatieve pijn, opiaatgebruik, opnameduur en complicaties.

\section{Resultaten}

Er werden geen significante verschillen gevonden in de QoR-40-scores tussen de beide groepen. De patiënten bleken echter met het diepe neuromusculaire blok zes uur na operatie tijdens beweging wel minder wondpijn te hebben (3,02 vs. 4,$06 ; p=0,028)$ en minder diepe buikpijn op de eerste dag postoperatief $(2,92 v s .4,06 ; p=0,031)$. Dit ging tevens gepaard met minder opiaatgebruik op dag $1(16,02 \mathrm{mg}$ vs. $21,41 \mathrm{mg} ; p=0,033)$. Een significant groter aandeel van de groep patiënten met diepe spierverslapping kon reeds op dag 2 met ontslag (50\% vs. 29,8\%; $p=0,044)$. Er was geen significant verschil in het antal complicaties tussen beide groepen.

\section{Conclusie}

Het gebruik van diepe spierverslapping tijdens laparoscopische donornefrectomie leidt tot lagere pijnscores en minder opiaatgebruik vroeg postoperatief.

\section{7. ${ }^{18} \mathrm{~F}$-fluorodeoxyglucose $\mathrm{PET} / \mathrm{CT}$ voor klinische stadiëring van patiënten met een urotheelcarcinoom van de hoge urinewegen}

\author{
D. Schweitzer, T. Muilwijk, S. Joniau, A. Necchi, M. Azizi, \\ E. Van Werkhoven, B.W.G. van Rhijn, S.F Shariat, E. Xylinas, \\ E. Vegt en K. Hendricksen \\ Antoni van Leeuwenhoek, Amsterdam
}

\section{Introductie}

Er is weinig bekend over de waarde van PET - in aanvulling op CT-onderzoek - voor de stadiëring van urotheelcarcinoom (UC) van de hoge urinewegen (UTUC). Deze studie bestudeert de nauwkeurigheid van PET/CT in het bepalen van $\mathrm{T}$ - en $\mathrm{N}$-stadium van UTUC.

\section{Materiaal en methoden}

Vijf centra includeerden 106 patiënten die een ${ }^{18} \mathrm{~F}$-fluorodeoxyglucose positron emission tomography/computed tomography $\left({ }^{18} \mathrm{FDG}-\mathrm{PET} / \mathrm{CT}\right)$ ondergingen, gevolgd door nefro-ureterectomie, nefrectomie of ureterectomie, met of zonder retroperitoneale lymfeklierdissectie (RPLND) in de periode 2007-2017. PET/CT-verslagen werden vergeleken met beschikbare histologie- en contrast enhanced CT (CECT) verslagen.

\section{Resultaten}

Op PET/CT was het klinisch T-stadium (cT) van 13 UTUC T0, 79 T1-4 en 14 Tx, waarmee 93 van 106 (88\%) UTUC FDG-avide waren. Na correctie voor neoadjuvante chemotherapie $(n \mathrm{AC})(n=23)$ werd bij 74 patiënten $\mathrm{cT}$ vergeleken met het pathologisch T-stadium (pT). pT werd door PET/CT correct voorspeld bij 25 (34\%) UTUC-patiënten, onderschat bij 29 (39\%) en overschat bij 20 (27\%) patiënten. Op de PET/CT-scan was het klinisch N-stadium $(\mathrm{cN})$ bij patiënten met een FDG-avide UTUC $(n=93)$ N0 bij 63 patiënten, en N1-3 bij 30. De 13 patiënten met cT0 hadden allen $\mathrm{cN} 0$. Na correctie voor NAC werd bij 47 patiënten een RPLND uitgevoerd. 34 cN0-patiënten hadden 31 pN0 en 3 pN1. 13 cN13 patiënten hadden $4 \mathrm{pN} 0$ en $9 \mathrm{pN} 1$. Daarmee bleken 3 PET/ CT-scans fout-negatief en 4 fout-positief voor cN, resulterend in $75 \%$ sensitiviteit, $89 \%$ specificiteit, $69 \%$ positive 
predictive value (PPV) en 91\% negative predictive value (NPV). 64 CE-CT-verslagen waren beschikbaar. Door gebruik van PET/CT in aanvulling op CE-CT werd bij 8 (13\%) patiënten $\mathrm{cN}$ opgewaardeerd, waarvoor bij 7 patiënten NAC werd gestart. Bij 2 (3\%) patiënten gaf PET/CT een onderwaardering.

\section{Conclusie}

Op PET/CT bleek $88 \%$ van de onderzochte UTUC FDG-avide. Het cT werd bij 34\% van de patiënten correct voorspeld, bij $39 \%$ onderschat en bij $27 \%$ overschat. Het gebruik van ${ }^{18} \mathrm{FDG}-\mathrm{PET} / \mathrm{CT}$ in aanvulling op CE-CT resulteerde in opwaardering van $\mathrm{cN}$ bij $8(13 \%)$ patiënten en onderwaardering bij $2(3 \%)$ patiënten. De resultaten van ${ }^{18}$ FDG-PET/CT bij patiënten met UTUC suggereren een meerwaarde in de diagnostiek naar $\mathrm{cN}$.

\section{Moleculaire markers verbeteren de EAU- risicostratificatie voor de kans op progressie bij patiënten met niet-spierinvasieve blaaskanker}

\author{
K.E. van Kessel, J.L. Boormans, K.A. van der Keur, W. Beukers \\ en E.C. Zwarthoff \\ Erasmus MC, Rotterdam
}

\section{Introductie}

De richtlijn van de European Association of Urology (EAU) adviseert patiënten met niet-spierinvasieve blaaskanker (NSIBK) te stratificeren voor het risico op recidief en progressie aan de hand van klinische en pathologische karakteristieken. Wij onderzochten de toegevoegde waarde van moleculaire markers aan de bestaande EAU-classificatie voor de kans op progressie naar spierinvasieve blaaskanker (SIBK).

\section{Materiaal en methoden}

In totaal werden 1239 patiënten met NSIBK (47\% primaire en $53 \%$ recidieftumoren) prospectief geïncludeerd in zes Europese centra en METC-goedkeuring was verkregen in alle centra. DNA werd geïsoleerd uit vers tumormateriaal en geanalyseerd voor mutaties in FGFR3, PIK3CA, RAS en TERT en methylering van GATA2, TBX2, TBX3 en ZIC4. Middels Cox-regressieanalyse werden markers geïdentificeerd die correleerden met tijd tot progressie naar SIBK. De mate van progressie-incidentie (PI) per 100 patiëntjaren werd berekend voor subgroepen van patiënten.

\section{Resultaten}

Volgens de EAU-classificatie hadden 276 patiënten een laag, 273 een intermediair en 555 een hoog risico op progressie. De mediane follow-up was 27 maanden (range 0-81) en progressie naar SIBK trad op bij 57 patiënten
(4,6\%). FGFR3-mutaties en methylering van GATA2 en $T B X 3$ waren significant geassocieerd met progressievrije overleving: hazard ratio's (HR) resp. 0,34, 2,53 en 2,64. De mate van PI voor de 555 patiënten met een hoog risico op progressie volgens de EAU-classificatie was 4,25. Multivariate analyse toonde dat FGFR3-mutatiestatus en methylering van GATA2 deze categorie stratificeerden bij patiënten met een lage (PI $=0,86 ; 26 \%$ van de populatie), een intermediaire ( $\mathrm{PI}=4,32 ; 50 \%$ van de populatie) en een hoge kans (PI $=7,66 ; 24 \%$ van de populatie) op progressie.

\section{Conclusie}

Moleculaire markers verbeteren de risicostratificatie van patiënten met NSIBK die volgens de EAU-classificatie een verhoogde kans hebben op progressie naar SIBK. Patiënten met tumoren met wildtype $F G F R 3$ en methylering van GATA2 hebben een zeer hoog risico op progressie, en direct radicale cystectomie lijkt de meest aangewezen behandeling voor deze patiënten.

\section{FLEXSEM-studie. Proximale uretersteen: met flexibele of semirigide URS te benaderen?}

\author{
A.S. Figdor, B.M.A. Schout, M.M. Nijenhuis, H. Putter en \\ R.C.M. Pelger \\ Alrijne Ziekenhuis, Leiderdorp
}

\section{Introductie}

In de NVU/EAU-richtlijnen staan geen adviezen ten aanzien van keuze voor flexibele (FURS) vs. semirigide URS (SURS) wat betreft benadering van proximale ureterstenen. De AUA adviseert om een FURS beschikbaar te hebben. De stijgende prevalentie van urolithiasis en de steeds technischer en duurder wordende behandeling maken urolithiasis de op een na duurste ziekte van de urologie. De FURS is over het algemeen een duurdere ingreep dan de SURS. De FLEXSEM-studie onderzoekt de vraag: zijn FURS en SURS even succesvol voor de proximale uretersteenbehandeling?

\section{Materiaal en methoden}

In vier centra werden 182 patiënten met een proximale uretersteen (FURS: $n=96$; SURS: $n=86$ ) onderling vergeleken op: succesvolle operatie (toegang tot en succesvol verwijderen van de steen); steenvrij zijn per-/postoperatief; complicaties per-/postoperatief en re-interventies. Proximale uretersteen werd gedefinieerd van UPJ tot iliacale vaten. Een onafhankelijke radioloog beoordeelde alle beeldvorming pre- en postoperatief. Steenvrij postoperatief is gedefinieerd als geen stenen $\geq 1 \mathrm{~mm}$. 


\section{Resultaten}

De resultaten van deze FLEXSEM-studie toonden geen verschil tussen de FURS en SURS voor de proximale uretersteen op alle hier genoemde onderzochte parameters $(p>0,05)$. Zie figuur 29.1. Volledig steenvrij peroperatief volgens oordeel van de uroloog was $38,5 \%$ en $43,0 \%$ (FURS en SURS), loosbaar gruis bij einde ingreep was $38,5 \%$ en $33,7 \%$ en niet steenvrij peroperatief was $22,9 \%$ en $23,3 \%$ $(p=0,772)$. In $74,0 \%$ van de FURS en $69,7 \%$ van de SURS was postoperatief beeldvorming verricht. Van deze groep was $56,3 \%$ (FURS) en $51,7 \%$ (SURS) postoperatief volledig steenvrij $(p=0,593)$. Re-interventies werden in $11,8 \%$ verricht indien er geen beeldvorming postoperatief was, $9,9 \%$ indien steenvrij was en $46,7 \%$ indien niet steenvrij was. De meest voorkomende peroperatieve complicaties waren ureterperforatie en bloeding. Postoperatief waren dit voornamelijk infecties.

\section{Conclusie}

Voor de proximale uretersteen zijn FURS en SURS even succesvol. Gezien de stijgende prevalentie en kosten van

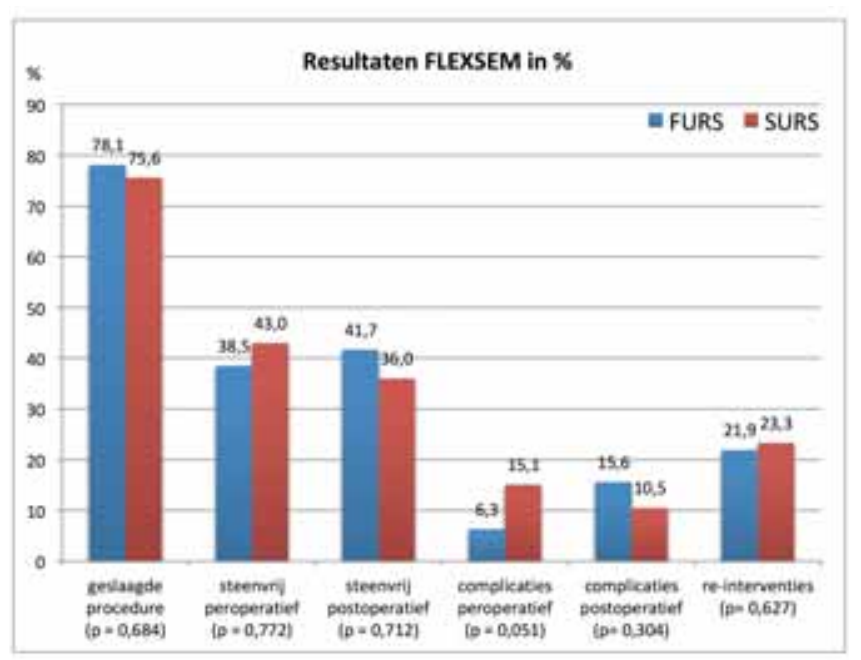

Figuur 29.1

urolithiasisbehandelingen adviseren we om FURS versus SURS bewust te overwegen. 